Prepared in cooperation with the Missouri Department of Natural Resources

\title{
Quality of Surface Water in Missouri, Water Year 2017
}

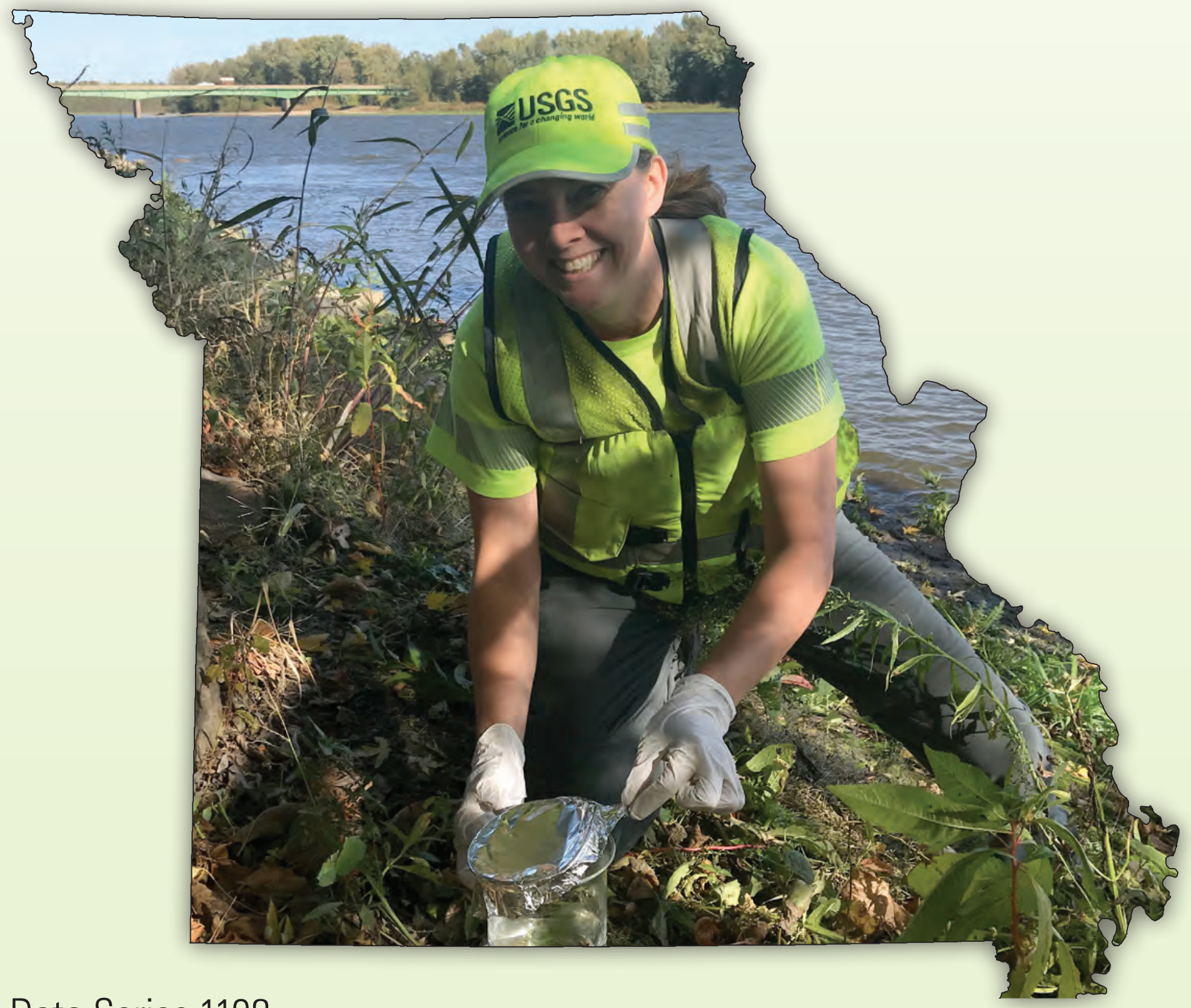

Data Series 1108 

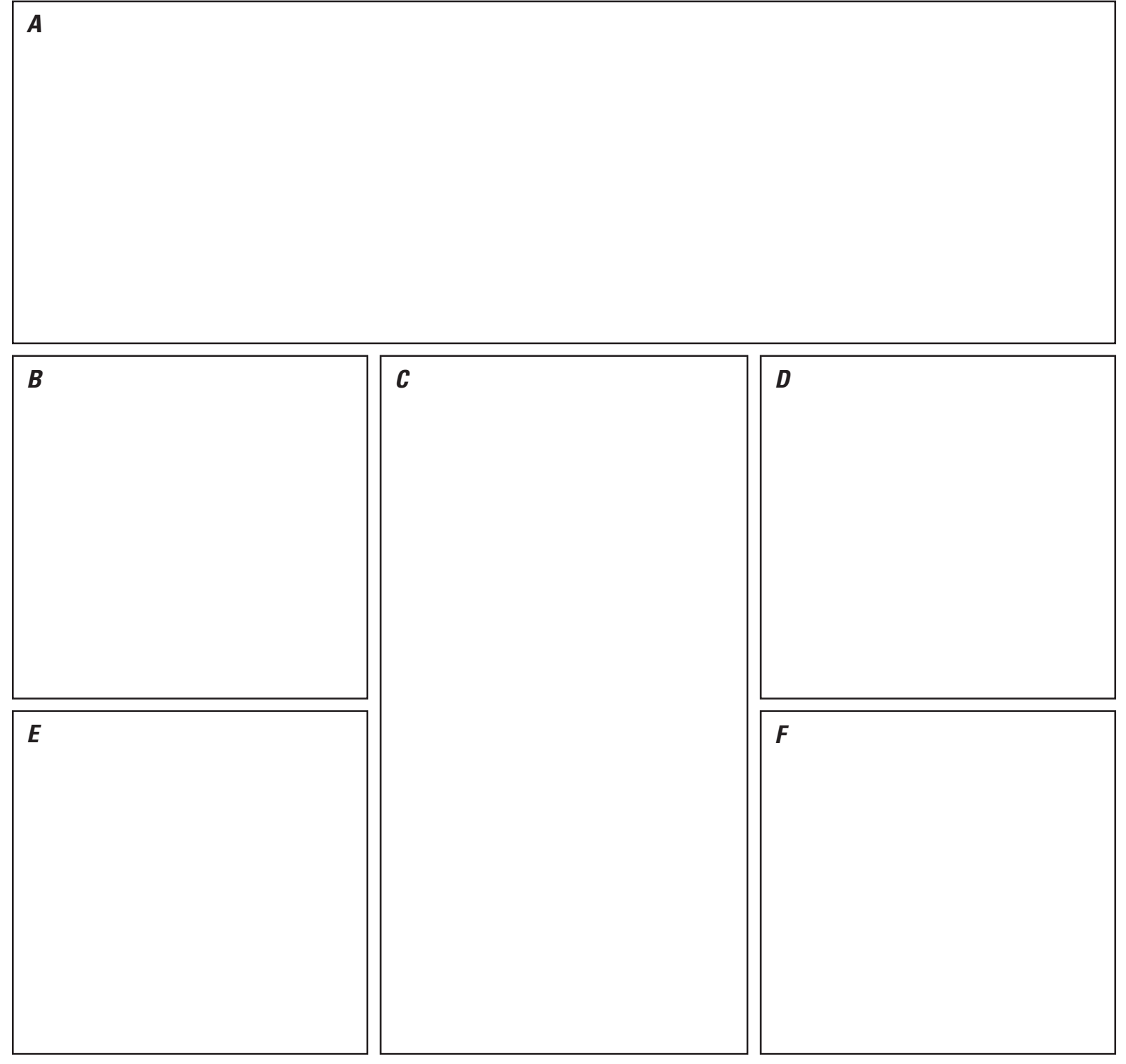

Cover. Hydrologist collecting nutrient data from the air and a nearby stream (shown within Missouri State boundary).

\section{Back cover.}

$A$, Hydrologist collecting a surface-water quality sample during flooding conditions using a large sampler and mechanical reel from a bridge deck.

$B$, Hydrologic technicians collecting suspended-sediment samples from a boat deck on the Mississippi River. $C$, Hydrologic technician processing a surface-water quality sample for chemical analysis.

$D$, Hydrologist operating an electrical reel and large sampler from a boat deck to collect a surface-water quality sample on the Mississippi River.

$E$, Hydrologist processing fecal bacteria indicator samples from a mobile laboratory.

$F$, Hydrologic technician collecting a surface-water quality sample from a small stream. 


\section{Quality of Surface Water in Missouri, Water Year 2017}

By Miya N. Barr and Katherine A. Bartels

Prepared in cooperation with the Missouri Department of Natural Resources

Data Series 1108 


\title{
U.S. Department of the Interior \\ DAVID BERNHARDT, Acting Secretary
}

\author{
U.S. Geological Survey \\ James F. Reilly II, Director
}

U.S. Geological Survey, Reston, Virginia: 2019

For more information on the USGS - the Federal source for science about the Earth, its natural and living resources, natural hazards, and the environment-visit https://www.usgs.gov or call 1-888-ASK-USGS.

For an overview of USGS information products, including maps, imagery, and publications,

visit https://store.usgs.gov.

Any use of trade, firm, or product names is for descriptive purposes only and does not imply endorsement by the U.S. Government.

Although this information product, for the most part, is in the public domain, it also may contain copyrighted materials as noted in the text. Permission to reproduce copyrighted items must be secured from the copyright owner.

Suggested citation:

Barr, M.N., and Bartels, K.A., 2019, Quality of surface water in Missouri, water year 2017: U.S. Geological Survey Data Series 1108, 25 p., https://doi.org/10.3133/ds1108.

ISSN 2327-638X (online) 


\section{Contents}

Abstract

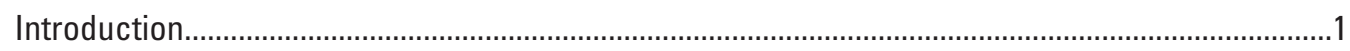

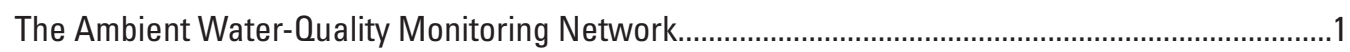

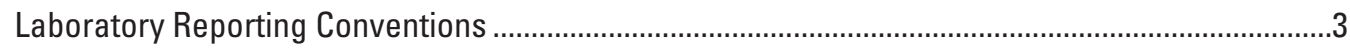

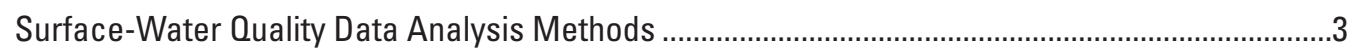

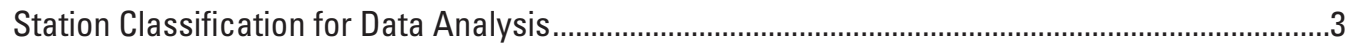

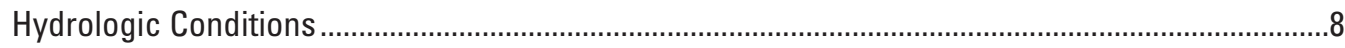

Distribution, Concentration, and Detection Frequency of Selected Constituents ............................11

Physical Properties, Suspended-Solids Concentration, Suspended-Sediment

Concentration, and Fecal Indicator Bacteria Density.................................................11

Dissolved Nitrate plus Nitrite and Total Phosphorus Concentrations ....................................11

Dissolved and Total Recoverable Lead and Zinc Concentrations .........................................11

Selected Pesticide Concentrations and Detection Frequencies...............................................21

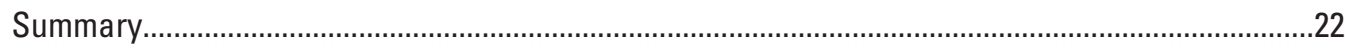

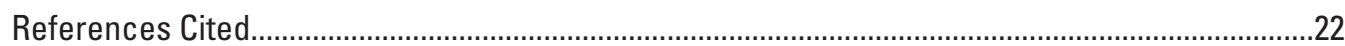

\section{Figures}

1. Map showing physiographic regions of Missouri as well as location and class of selected surface-water quality monitoring stations, water year 2017 .............................6

2. Map showing land use in Missouri.............................................................................

3. Map showing location of selected streamflow-gaging stations used to provide a summary of hydrologic conditions within Missouri, water year 2017 ............................

4. Graphs showing monthly mean streamflow for water year 2017 and long-term mean monthly streamflow at six representative streamflow-gaging stations in Missouri

5. Boxplots showing distribution of physical properties, suspended-solids concentrations, and suspended-sediment concentrations from surface-water quality stations in Missouri, water year 2017.

6. Boxplots showing distribution of fecal indicator bacteria density in samples from surface-water quality stations in Missouri, water year 2017.

7. Boxplots showing distribution of dissolved nitrate plus nitrite as nitrogen and total phosphorus concentrations in samples from surface-water quality stations in Missouri, water year 2017.

8. Boxplots showing distribution of dissolved and total recoverable lead and zinc concentrations from surface-water quality stations in Missouri, water year 2017

9. Graphs showing detection of selected pesticides in samples from selected surface-water quality stations, water year 2017. 


\section{Tables}

1. U.S. Geological Survey station number, name, contributing drainage area, sampling frequency, station class, and station type for selected surface-water-quality monitoring stations in Missouri, water year 2017

2. Station classes and number of stations in each class and type for Missouri, water year 2017

3. Peak streamflow for water year 2017 and periods of record for selected streamflow-gaging stations in Missouri

4. Seven-day low flow for water year 2017, period of record 7-day low flow, minimum daily mean streamflow for water year 2017, and period of record minimum daily mean streamflow for selected streamflow-gaging stations in Missouri

\section{Conversion Factors}

U.S. customary units to International System of Units

\begin{tabular}{|c|c|c|}
\hline Multiply & By & To obtain \\
\hline \multicolumn{3}{|c|}{ Length } \\
\hline inch (in.) & 2.54 & centimeter $(\mathrm{cm})$ \\
\hline mile (mi) & 1.609 & kilometer (km) \\
\hline \multicolumn{3}{|c|}{ Area } \\
\hline square mile $\left(\mathrm{mi}^{2}\right)$ & 2.590 & square kilometer $\left(\mathrm{km}^{2}\right)$ \\
\hline \multicolumn{3}{|c|}{ Flow rate } \\
\hline cubic foot per second $\left(\mathrm{ft}^{3} / \mathrm{s}\right)$ & 0.02832 & cubic meter per second $\left(\mathrm{m}^{3} / \mathrm{s}\right)$ \\
\hline
\end{tabular}

Temperature in degrees Celsius $\left({ }^{\circ} \mathrm{C}\right)$ may be converted to degrees Fahrenheit $\left({ }^{\circ} \mathrm{F}\right)$ as follows:

$$
{ }^{\circ} \mathrm{F}=\left(1.8 x^{\circ} \mathrm{C}\right)+32
$$

Horizontal coordinate information is referenced to the North American Datum of 1983 (NAD 83).

Specific conductance is given in microsiemens per centimeter at 25 degrees Celsius $(\mu \mathrm{S} / \mathrm{cm}$ at $\left.25^{\circ} \mathrm{C}\right)$.

Density population of bacteria is given in colonies per 100 milliliters $(\mathrm{col} / 100 \mathrm{~mL})$ of water.

Concentrations of chemical constituents in water are given either in milligrams per liter (mg/L) or micrograms per liter $(\mu \mathrm{g} / \mathrm{L})$.

A water year in U.S. Geological Survey reports is the 12-month period October 1 through September 30 and is designated by the calendar year in which it ends; thus, the year ending September 30, 2017, is called "water year 2017." 


\section{Abbreviations}

AWOMN Ambient Water-Quality Monitoring Network

E. coli Escherichia coli

LRL laboratory reporting level

LT-MDL long-term method detection level

MDL method detection level

MDNR Missouri Department of Natural Resources

MRL minimum reporting level

NASQAN National Stream Quality Assessment Network

NWIS National Water Information System

NWOL National Water Quality Laboratory

TMDL total maximum daily load

USGS U.S. Geological Survey 



\title{
Quality of Surface Water in Missouri, Water Year 2017
}

\author{
By Miya N. Barr and Katherine A. Bartels
}

\section{Abstract}

The U.S. Geological Survey, in cooperation with the Missouri Department of Natural Resources, designed and operates a network of monitoring stations on streams and springs throughout Missouri known as the Ambient Water-Quality Monitoring Network. During water year 2017 (October 1, 2016, through September 30,2017), data presented in this report were collected at 72 stations: 70 Ambient Water-Quality Monitoring Network stations and 2 U.S. Geological Survey National Stream Quality Assessment Network stations. Among the 72 stations in this report, 4 stations have data presented from additional sampling performed in cooperation with the U.S. Army Corps of Engineers. Summaries of the concentrations of dissolved oxygen, specific conductance, water temperature, suspended solids, suspended sediment, Escherichia coli bacteria, fecal coliform bacteria, dissolved nitrate plus nitrite as nitrogen, total phosphorus, dissolved and total recoverable lead and zinc, and selected pesticide compounds are presented. Most of the stations have been classified based on the physiographic province or primary land use in the watershed represented by the station. Some stations have been classified based on the unique hydrology of the waterbodies they monitor. A summary of hydrologic conditions in the State including peak streamflows, monthly mean streamflows, and 7-day low flows also are presented.

\section{Introduction}

The Missouri Department of Natural Resources (MDNR) is responsible for the implementation of the Federal Clean Water Act (33 U.S.C. $\$ 1251$ et seq.) in Missouri. Section 305(b) of the Clean Water Act requires that each State develop a water-quality monitoring program and periodically report the status of its water quality (U.S. Environmental Protection Agency, 1997). Water-quality status is described in terms of the suitability of the water for various uses, such as drinking, fishing, swimming, and supporting aquatic life; these uses formally were defined as "designated uses" in State and Federal regulations. Section 303(d) of the Clean Water Act requires States to identify impaired waters and determine the total maximum daily loads (TMDLs) of pollutants that can be present in these waters and still meet applicable water-quality standards for their designated uses (U.S. Environmental Protection Agency, 2018). A TMDL addresses a single pollutant for each waterbody.

Missouri has an area of about 69,000 square miles and an estimated population of 6.09 million people (U.S. Census Bureau, 2016). Within Missouri, 115,772 miles (mi) of classified streams support a variety of uses including wildlife, recreation, agriculture, industry, transportation, and public utilities, but only $24,761 \mathrm{mi}$ (or about 21 percent) were monitored, evaluated, and assessed in the State's most recent waterquality report (Missouri Department of Natural Resources, 2016a). Of these assessed stream miles, an estimated 5,307 mi fully support the designated uses, and an estimated 5,549 $\mathrm{mi}$ are impaired by various physical changes or chemical contaminants to the point that criteria for at least one of the designated uses no longer can be met (Missouri Department of Natural Resources, 2016a).

The purpose of this report is to summarize surface-water quality data collected for the MDNR-U.S. Geological Survey (USGS) cooperative Ambient Water-Quality Monitoring Network (AWQMN) for water year 2017. The annual summary of select constituents provides MDNR with current information to assess the quality of surface water within the State and ensure the objectives of the AWQMN are being met. This report is one in a series of annual summaries (Otero-Benitez and Davis, 2009a, 2009b; Barr, 2010, 2011, 2013, 2014, 2015; Barr and Schneider, 2014; Barr and Heimann, 2016; Barr and Bartels, 2018). Data on the physical characteristics and waterquality constituents in samples collected during the 2017 water year are presented in figures and tables for 72 surface-water stations located throughout the State.

\section{The Ambient Water-Quality Monitoring Network}

The USGS, in cooperation with the MDNR, collects surface-water quality data pertaining to water resources in Missouri each water year (October 1 through September 30). These data, stored and maintained in the USGS National Water Information System (NWIS) database (U.S. Geological Survey, 2017), are collected as part of the Missouri AWQMN. The data collected for the AQWMN constitute a permanent source of accessible, accurate, impartial, and timely information for 
developing an enhanced understanding of the State's water resources. Historical surface-water quality data were published annually in the Water-Data Report series from water years 1964 through 2005 (U.S. Geological Survey, 1964-2005). Published data for the 2006 through 2010 water years can be accessed at https://wdr.water.usgs.gov/ (U.S. Geological Survey, 2006b-2010). Beginning in water year 2011, discrete water-quality data were no longer published annually but can be accessed in the NWIS database (U.S. Geological Survey, 2017).

The objectives of the AWQMN are to (1) obtain data on the quality and quantity of surface water within the State; (2) provide a database of historical water-quality information that can be used by the State planning and management agencies to make informed decisions about anthropogenic effects (such as agriculture, mining, and urban) on the State's surface waters; and (3) provide for consistent methodology in data collection, laboratory analysis, and data reporting. Constituent concentration data from the AWQMN have been used to determine statewide water-quality status and long-term trends (Barr and Davis, 2010) to meet information needs of State agencies involved in water-quality planning and management. The data collected also provide support for the design, implementation, and evaluation of preventive and remediation programs.

The MDNR and the USGS established a fixed-station AWQMN in 1964 with 18 stations, 5 of which are being sampled currently (2018). The number of stations within the AWQMN has varied since its inception because of changes in the State's needs. During water year 2017, the AWQMN program consisted of 70 stations (69 primary stations and 1 alternate station). Alternate sampling stations have been established at streamflow-gaging stations near some primary AWQMN stations, and one such station, Drywood Creek near Deerfield, Missouri (06917680), was sampled in September 2017 because of dry conditions at East Drywood Creek at Prairie State Park, Mo. (06917630). Sampling frequency at each station is determined by several factors, including drainage basin size, potential effects from anthropogenic activities (such as agriculture, mining, and urban), history of chemical change, need for annual data, and cost. Each of the streams in the AWQMN is classified for one or more designated uses. For specific information on the designated uses applicable to the streams sampled in the AWQMN, refer to Missouri Department of Natural Resources (2016a; 2016b).

The unique eight-digit number used by the USGS to identify each surface-water station is assigned when a station is first established. The complete eight-digit number for each station includes a two-digit prefix that designates the primary river system (05 is the upper Mississippi River, 06 is the Missouri River, and 07 is the lower Mississippi River) plus a six-digit downstream-order number; for example, the station number 05587455 indicates the station is in the upper Mississippi River system (05), and the remaining six digits (587455) locate the station in downstream order. In this system, the station numbers increase downstream along the main stem. A station on a tributary that enters between two main stem stations is assigned a station number between them.

Constituents collected within the AWQMN have been established by the MDNR based on their data needs at each station. Samples were collected by USGS personnel; collection methods and techniques followed USGS protocol (U.S. Geological Survey, 2006a). Onsite measurements of dissolved oxygen, specific conductance, and water temperature were collected at each station according to procedures described in Wilde (variously dated). Water samples were collected and processed for fecal indicator bacteria [Escherichia coli (E. coli) and fecal coliform] densities using the membrane filtration procedure described in Myers and others (2014). Methods used by the USGS for collecting and processing representative samples for nutrients, primary chemical constituents, trace elements, suspended solids, suspended sediment, and pesticide analyses are presented in detail in U.S. Geological Survey (2006a), Guy (1969), Wilde and others (2004), and Sandstrom and Wilde (2014). All laboratory analyses were done by the USGS National Water Quality Laboratory (NWQL) in Lakewood, Colorado, according to procedures described in Garbarino and others (2006), Fishman (1993), Patton and Kryskalla (2011), Patton and Truitt (1992), Sandstrom and others (2001 and 2015), and Zaugg and others (1995). Suspended-sediment concentrations were computed according to procedures described in Guy (1969).

In addition to the surface-water quality data collected from the 70 stations that form the AWQMN, selected data collected as part of other cooperative efforts are included in this report to help summarize water-quality conditions across the State. Water samples also are collected by the USGS at two USGS National Stream Quality Assessment Network (NASQAN; a national water-quality sampling network operated by the USGS, see https://cida.usgs.gov/quality/rivers/ home) stations. Sediment samples collected at four USGS streamflow-gaging stations are presented in this report. These samples are collected as part of a larger monitoring effort in cooperation with the U.S. Army Corps of Engineers. The suspended-sediment concentration data in this report are provided for comparison to the State's total suspended solids criteria. The suspended-sediment data used in this report consist of composited cross-sectional concentrations and average cross-sectional concentrations computed from five depth-integrated samples within the cross section (Edwards and Glysson, 1999). 


\section{Laboratory Reporting Conventions}

The NWQL uses method reporting conventions (Childress and others, 1999) to establish the minimum concentration for which more than one qualitative measurement can be made. These reporting conventions are the minimum reporting level (MRL), the method detection level (MDL), and the laboratory reporting level (LRL). The MRL is defined by the NWQL as the smallest measured concentration of a substance that can be measured reliably using a given analytical method. The MDL is the minimum concentration of a substance that can be measured and reported with 99-percent confidence that the concentration is greater than zero. A longterm method detection level (LT-MDL) is a detection level obtained by determining the standard deviation of 24 or more MDL spiked-sample measurements for an extended period. The LRL is computed as twice the LT-MDL. Pesticide data in this report that are not reported as less than the LRL and are graphically displayed below the LRL are estimated values (Childress and others, 1999) and not considered detections.

\section{Surface-Water Quality Data Analysis Methods}

The distribution of select constituent data was displayed graphically using side-by-side boxplots (box and whiskers distributions; Helsel and Hirsch, 2002). The plots show the center of the data (median, the center line of the boxplot), the variation (interquartile range [25th to 75th percentiles] or the height of the box), the skewness (quartile skew, which is the relative size of the box halves), the spread (upper and lower adjacent values are the vertical lines or whiskers), and the presence or absence of unusual values or outliers. If the median equals the 25th and 75th percentiles, the boxplot is represented by a single horizontal line. Boxplots with censored data (suspended solids, dissolved nitrate plus nitrite as nitrogen, total phosphorus, and dissolved and total recoverable lead and zinc) were modified by making the lower limit of the box equal to the MRL or LT-MDL as appropriate. For pesticide concentration distributions, censored concentrations (reported as less than the LRL) were included in each distribution as a concentration value equal to the LRL. For some samples, pesticide concentrations are reported as estimated values (Childress and others, 1999), which are included in the distribution as a concentration that is plotted below the LRL and above the LT-MDL. All data used to generate the boxplots can be obtained from the NWIS database (U.S. Geological Survey, 2017). These data can be compiled by the public from NWIS using search criteria such as USGS station identifiers (table 1) and the desired date range.

\section{Station Classification for Data Analysis}

The stations used in this report are located throughout the State (fig. 1) and monitor watersheds with a variety of land uses (fig. 2) and unique hydrologic systems. Most of the stations were divided into first-order classifications according to the physiographic province (fig. 1) or the primary land use in the watershed represented by the station (fig. 2). Some stations were included in the same classification together according to the unique hydrologic characteristics of the water body they monitor (fig. 1). The physiography-based classes include the Dissected Till Plains (DTPL) in the north, the Osage Plains (OSPL) in the west-central, the Mississippi Alluvial Plain (MIALPL) in the southeast, the Salem Plateau (OZPLSA) in the middle of the State, and the Springfield Plateau (OZPLSP) in the southwest (fig. 1). Stations classified by type of land use include those where mining (MINING) and urban (URBAN) land uses were expected to have a substantial effect of water quality. Stations classified together based on the unique hydrologic characteristics of the water bodies they monitor refer to springs (SPRING) and the stations on the Mississippi River (BRMIG and BRMIT) and the Missouri River (BRMOSJ, BRMOS, and BRMOH), also referred to in this report as the "Big River stations" (fig. 1).

Some additional classifications were established to identify differences in drainage area and land use within physiographic regions. To account for these additional differences, each station that was classified by physiographic province was subdivided into second-order classifications. These secondorder classes are based on contributing drainage area (table 1) or land use within the watershed represented by the station (figs. 1, 2; table 2). The second-order classifications include watershed indicator (wi) stations and land-use indicators. Stations within the wi classes are the most downstream stations in a watershed having a drainage area greater than 1,000 square miles. Water-quality data obtained from wi stations can be interpreted as being representative of the general condition of the watershed. Land-use indicator stations include stations where forest (fo), agriculture (ag), or prairie (pr) is the predominate land use in the watershed upstream from the station. Water quality at land-use indicator stations is likely to be affected by a specific land use. When stations were in watersheds where multiple land uses were present, the convention was to mention them in predominant order. The agriculture and forest (ag/fo) land-use indicator, for example, implies that the primary land use of the watershed is agriculture, although a substantial part of the land use is forest (fig. 2).

Three stations from the AWQMN did not fit in the station classes defined for this report (table 2) and sampling results from these sites are not included. The three excluded stations were Cuivre River near Troy, Mo. (05514500), and Lamine River near Pilot Grove, Mo. (06907300), both within the Ozark Plateaus Province, and Lake Taneycomo at Branson, Mo. (07053700), a station on a semiriverine system downstream from a major impoundment. 
Table 1. U.S. Geological Survey station number, name, contributing drainage area, sampling frequency, station class, and station type for selected surface-water-quality monitoring stations in Missouri, water year 2017.

[Water year 2017 is defined as October 1, 2016, through September 30, 2017. USGS, U.S. Geological Survey; mi², square mile; DTPL, Dissected Till Plains; ag, agriculture; --, not applicable; BRMIG, Big River-Mississippi River below Grafton, Illinois; wi, watershed indicator; BRMOSJ, Big River—Missouri River at St. Joseph, Missouri; BRMOS, Big River-Missouri River at Sibley, Missouri; MINING, mining; OSPL, Osage Plains; pr, prairie; OZPLSP, Ozark Plateaus-Springfield Plateau; fo, forest; OZPLSA, Ozark Plateaus-Salem Plateau; SPRING, spring; BRMOH, Big River-Missouri River at Hermann, Missouri; URBAN, urban; BRMIT, Big River-Mississippi River at Thebes, Illinois; MIALPL, Mississippi Alluvial Plain]

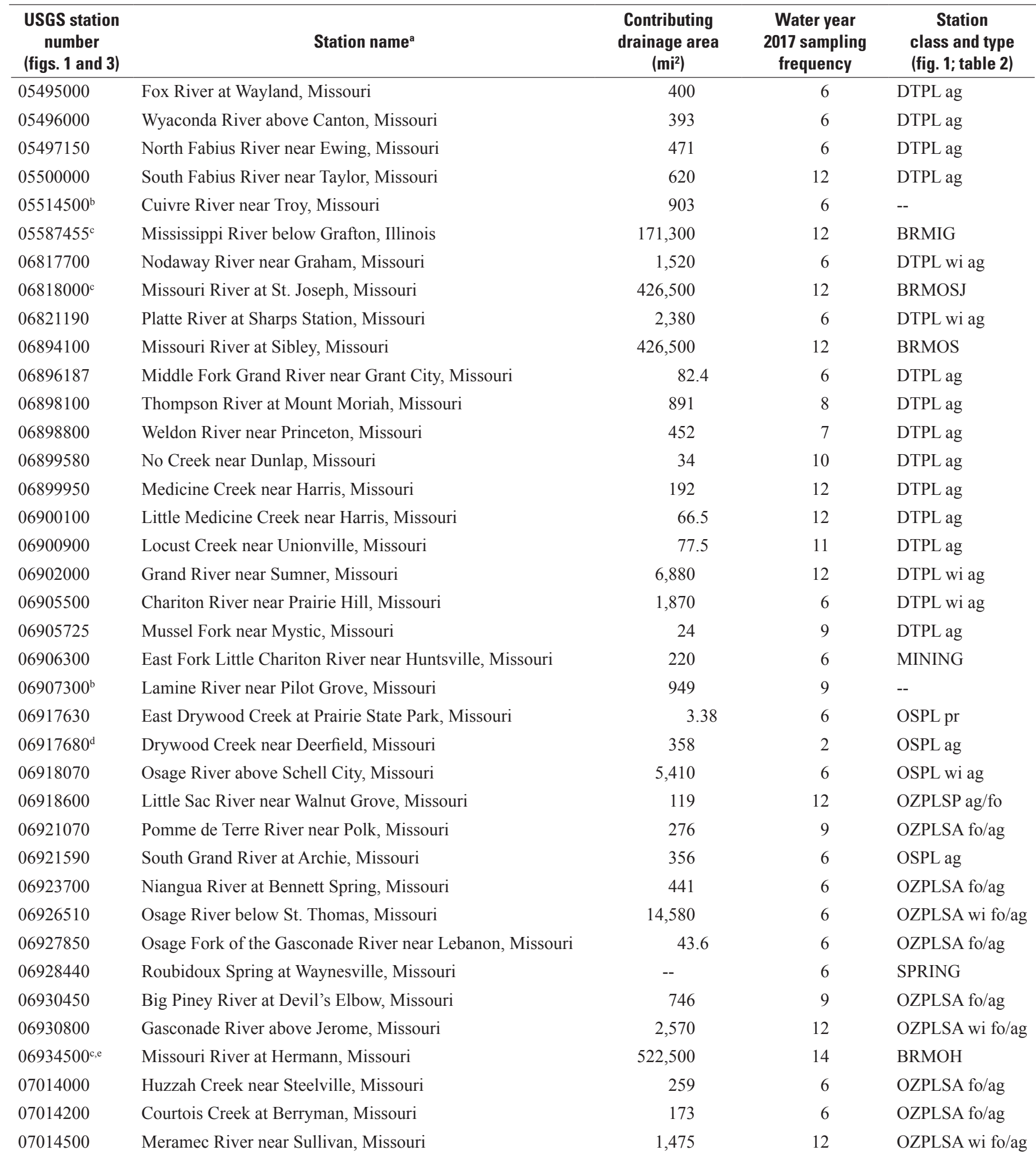


Table 1. U.S. Geological Survey station number, name, contributing drainage area, sampling frequency, station class, and station type for selected surface-water-quality monitoring stations in Missouri, water year 2017.-Continued

[Water year 2017 is defined as October 1, 2016, through September 30, 2017. USGS, U.S. Geological Survey; mi², square mile; DTPL, Dissected Till Plains; ag, agriculture; --, not applicable; BRMIG, Big River-Mississippi River below Grafton, Illinois; wi, watershed indicator; BRMOSJ, Big River-Missouri River at St. Joseph, Missouri; BRMOS, Big River-Missouri River at Sibley, Missouri; MINING, mining; OSPL, Osage Plains; pr, prairie; OZPLSP, Ozark Plateaus-Springfield Plateau; fo, forest; OZPLSA, Ozark Plateaus-Salem Plateau; SPRING, spring; BRMOH, Big River-Missouri River at Hermann, Missouri; URBAN, urban; BRMIT, Big River-Mississippi River at Thebes, Illinois; MIALPL, Mississippi Alluvial Plain]

\begin{tabular}{|c|c|c|c|c|}
\hline $\begin{array}{c}\text { USGS station } \\
\text { number } \\
\text { (figs. } 1 \text { and } 3 \text { ) }\end{array}$ & Station name ${ }^{a}$ & $\begin{array}{c}\text { Contributing } \\
\text { drainage area } \\
\left(\mathrm{mi}^{2}\right)\end{array}$ & $\begin{array}{c}\text { Water year } \\
2017 \text { sampling } \\
\text { frequency }\end{array}$ & $\begin{array}{c}\text { Station } \\
\text { class and type } \\
\text { (fig. 1; table 2) }\end{array}$ \\
\hline 07016400 & Bourbeuse River above Union, Missouri & 808 & 9 & OZPLSA fo/ag \\
\hline 07018100 & Big River near Richwoods, Missouri & 735 & 10 & MINING \\
\hline 07019280 & Meramec River at Paulina Hills, Missouri & 3,920 & 11 & URBAN wi \\
\hline 07020550 & South Fork Saline Creek near Perryville, Missouri & 55.3 & 6 & OZPLSA fo/ag \\
\hline $07022000^{c, e}$ & Mississippi River at Thebes, Illinois & 713,200 & 14 & BRMIT \\
\hline 07036100 & St. Francis River near Saco, Missouri & 664 & 9 & OZPLSA fo/ag \\
\hline 07037300 & Big Creek at Sam A. Baker State Park, Missouri & 189 & 6 & OZPLSA fo/ag \\
\hline 07042450 & St. Johns Ditch at Henderson Mound, Missouri & 313 & 7 & MIALPL \\
\hline 07052250 & James River near Boaz, Missouri & 462 & 6 & URBAN \\
\hline 07052345 & Finley Creek below Riverdale, Missouri & 261 & 12 & OZPLSP ag/fo \\
\hline 07052500 & James River at Galena, Missouri & 987 & 12 & URBAN \\
\hline 07052820 & Flat Creek below Jenkins, Missouri & 274 & 12 & OZPLSP ag/fo \\
\hline $07053700^{\mathrm{b}}$ & Lake Taneycomo at Branson, Missouri & -- & 6 & -- \\
\hline 07053900 & Swan Creek near Swan, Missouri & 148 & 6 & OZPLSA fo/ag \\
\hline 07057500 & North Fork River near Tecumseh, Missouri & 561 & 6 & OZPLSA fo/ag \\
\hline 07057750 & Bryant Creek below Evans, Missouri & 214 & 6 & OZPLSA fo/ag \\
\hline 07061600 & Black River below Annapolis, Missouri & 493 & 8 & OZPLSA fo/ag \\
\hline 07185764 & Spring River above Carthage, Missouri & 425 & 12 & OZPLSP ag/fo \\
\hline 07186480 & Center Creek near Smithfield, Missouri & 303 & 9 & MINING \\
\hline 07186600 & Turkey Creek near Joplin, Missouri & 41.8 & 9 & URBAN \\
\hline 07187000 & Shoal Creek above Joplin, Missouri & 427 & 12 & OZPLSP ag/fo \\
\hline 07188838 & Little Sugar Creek near Pineville, Missouri & 195 & 12 & OZPLSP ag/fo \\
\hline 07189000 & Elk River near Tiff City, Missouri & 872 & 12 & OZPLSP ag/fo \\
\hline 07189100 & Buffalo Creek at Tiff City, Missouri & 60.8 & 12 & OZPLSP ag/fo \\
\hline
\end{tabular}

a Station names were obtained from the U.S. Geological Survey National Water Information System database (U.S. Geological Survey, 2017).

${ }^{b}$ Station data are not included in this report because this station does not fit within the classification system used for this report.

'Additional water temperature and suspended-sediment samples were collected at this station in cooperation with the U.S. Army Corps of Engineers.

${ }^{\mathrm{d}}$ This station was sampled as an alternate station when East Drywood Creek at Prairie State Park, Missouri (06901870) was dry.

eStations 06934500 and 07022000 are not part of the Ambient Water-Quality Monitoring Network but were used in this report. Stations 06934500 and 07022000 are funded by the U.S. Geological Survey National Stream Quality Assessment Network. 

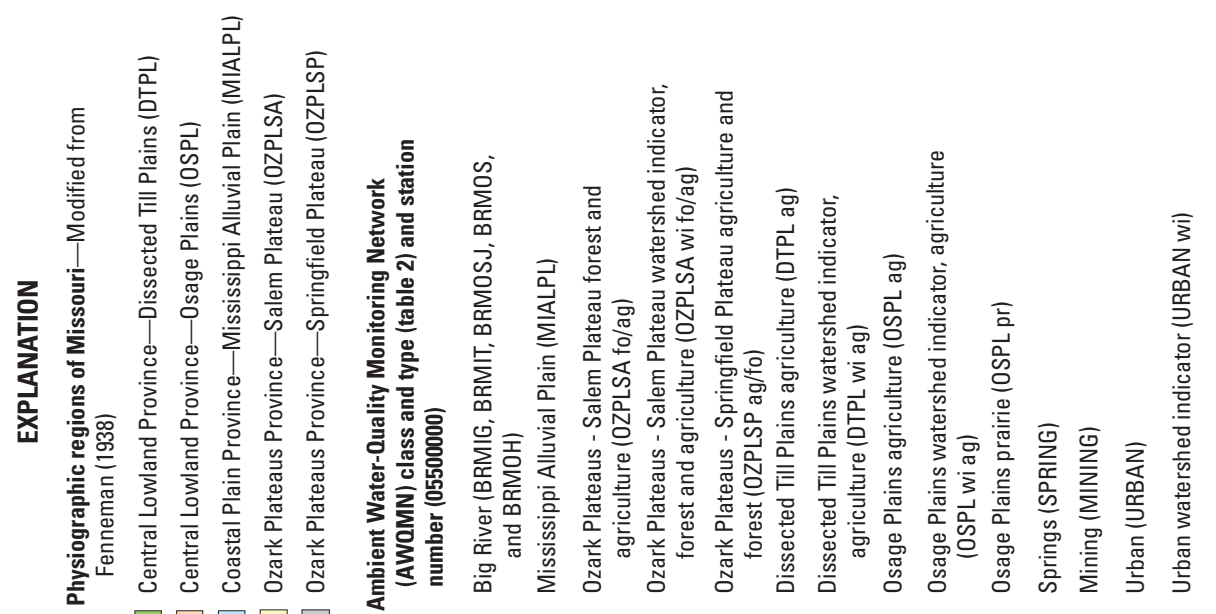

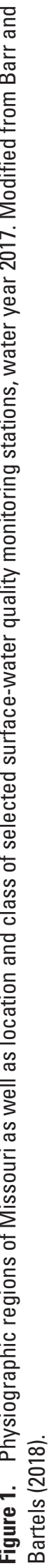

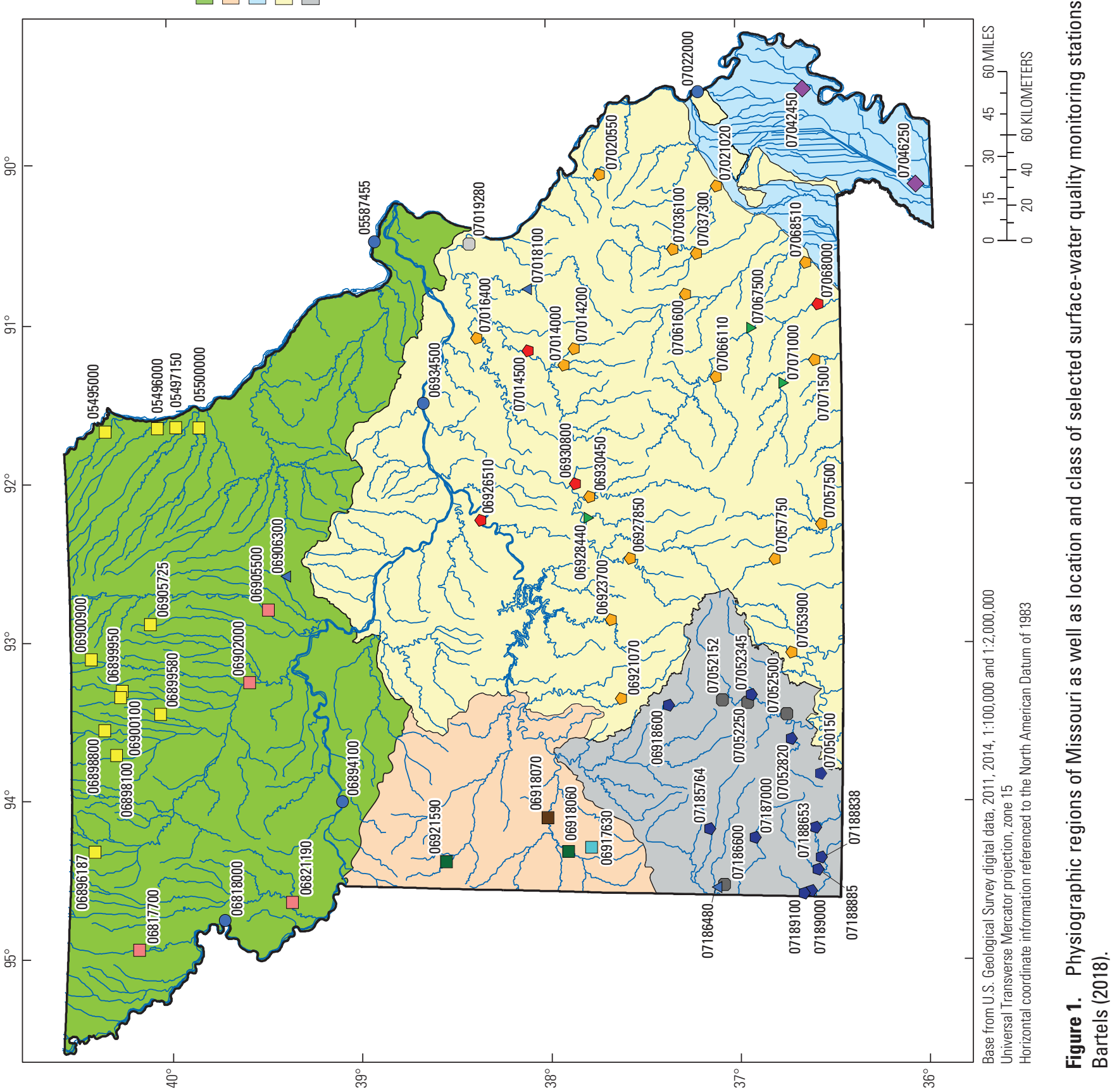




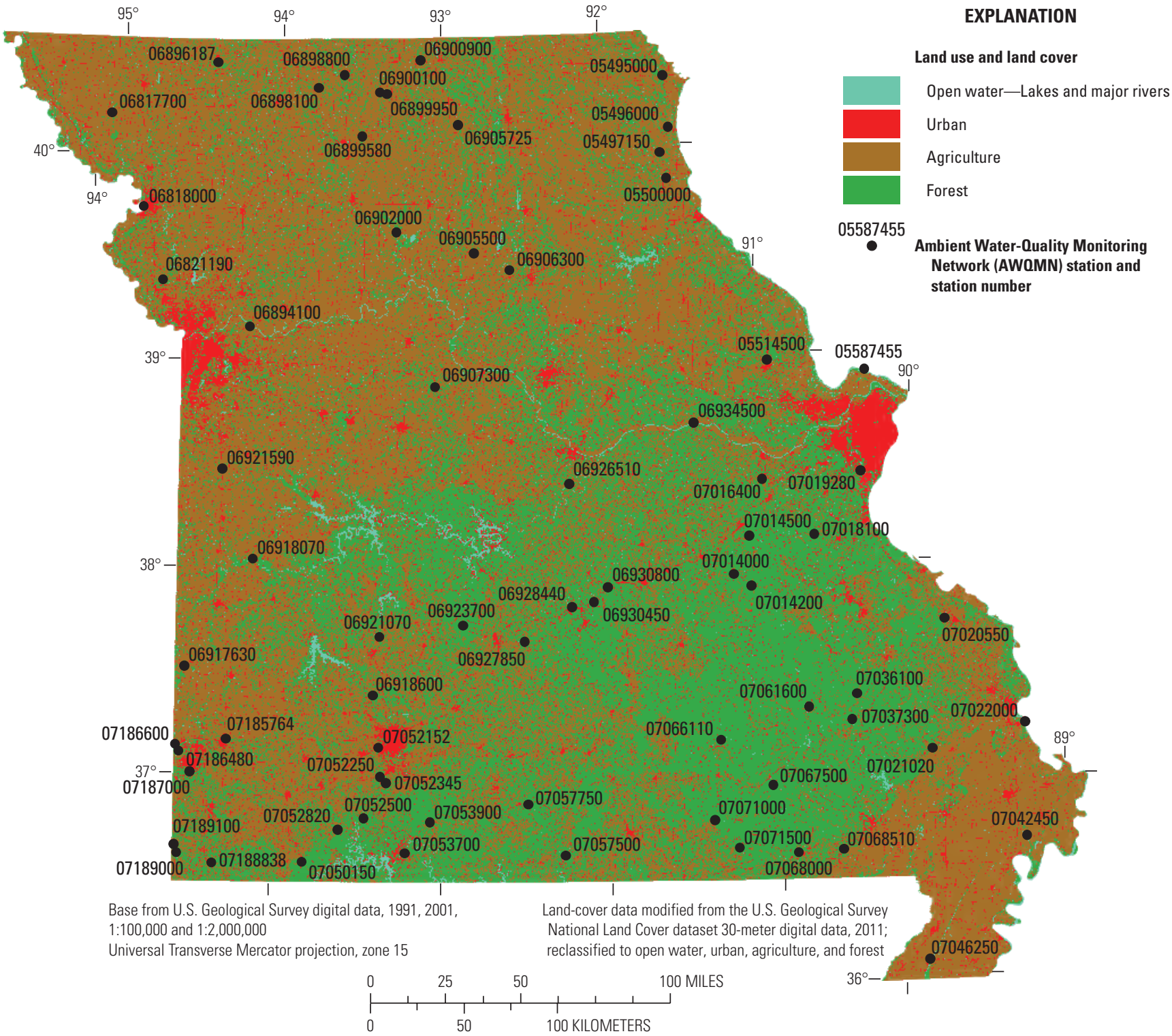

Figure 2. Land use in Missouri. Modified from Barr and Bartels (2018). 
Table 2. Station classes and number of stations in each class and type for Missouri, water year 2017.

[Classification system is based on physiography of the State, primary and secondary land use and coverage, unique station type, and drainage area; as well as a station's representativeness to the general condition of the watershed. See the "Station Classification for Data Analysis" section of this report for the full explanation of station classes and types]

\begin{tabular}{|c|c|c|}
\hline \multicolumn{2}{|r|}{ Station class and type (fig. 1) } & \multirow{2}{*}{$\begin{array}{c}\text { Number of stations } \\
\text { (table 1) }\end{array}$} \\
\hline Abbreviation & Definition & \\
\hline BRMIG & Big River-Mississippi River below Grafton, Illinois & 1 \\
\hline BRMOSJ & Big River-Missouri River at St. Joseph, Missouri & 1 \\
\hline BRMOS & Big River-Missouri River at Sibley, Missouri & 1 \\
\hline OZPLSA fo/ag & Ozark Plateaus - Salem Plateau forest and agriculture & 18 \\
\hline OZPLSA wi fo/ag & Ozark Plateaus - Salem Plateau watershed indicator, forest and agriculture & 4 \\
\hline OZPLSP ag/fo & Ozark Plateaus - Springfield Plateau agriculture and forest & 9 \\
\hline DTPL ag & Dissected Till Plains agriculture & 12 \\
\hline OSPL pr & Osage Plains prairie & 1 \\
\hline SPRING & Springs & 3 \\
\hline MINING & Mining & 3 \\
\hline URBAN & Urban & 4 \\
\hline URBAN wi & Urban watershed indicator & 1 \\
\hline
\end{tabular}

${ }^{a}$ One station in this class, Little River Ditches near Rives, Missouri (07046250), has a drainage area greater than 1,000 square miles but is not considered a watershed indicator station because the man-made canals and ditches within its drainage area are not connected hydrologically.

\section{Hydrologic Conditions}

Surface-water streamflow varies seasonally in Missouri and tends to reflect precipitation patterns, as well as land uses and water management practices (Slater and Villarini, 2017). During water year 2017, the average annual precipitation of the conterminous United States was 3.36 inches (in.) greater than the 20th century average of 29.94 in. (National Oceanic and Atmospheric Administration, 2018a). Total precipitation across Missouri during water year 2017 was 40.62 in., which was essentially equal to the 20th century State precipitation average of 40.50 in. (National Oceanic and Atmospheric Administration, 2018b).

The streamflow-gaging stations (hereinafter referred to as "streamgages"), whose data were used to identify the variation in hydrologic conditions described in this report, were selected based on their geographical distribution across the State (fig. 3) and long period of available streamflow information. Each streamgage has a period of record of at least 47 years. This summary of statewide hydrologic condition data for the current (2017) water year in comparison to historical conditions is a legacy of information, including the streamgages used, that was previously provided in the annual Water-Data Reports (U.S. Geological Survey, 1964-2005).

Data from six streamgages distributed throughout the state (fig. 4) were used to compare water year 2017 monthly mean streamflow to the long-term mean monthly streamflow and to demonstrate how streamflow can vary across the State. Monthly mean streamflow is the arithmetic mean of daily streamflow for a given month. For comparison to water year 2017, a long-term mean was attained from all monthly mean streamflows for the available period of record. Of these six streamgages, three $(05495000,06921590$, and 07052500) are part of the AWQMN and the remaining three streamgages (06897500, 06933500, and 07067000) only record streamflow and are not part of the AWQMN (table 1; figs. 3, 4). Monthly mean streamflows in April 2017 were higher than the long-term mean for all six streamgages (fig. 4). The two western-most sites used for the legacy streamflow information (06897500 and 06921590) had monthly mean streamflows in July 2017 greater than the long-term mean monthly 
streamflows. Streamflow from October 2016 through February 2017 was less than the long-term streamflow at every streamgage, except 06897500 in October and January, and 07067000 in October.

Peak streamflow and 7-day low flow values (the smallest values of mean streamflow computed during any 7 consecutive days during the analysis period) for nine streamgages are presented in tables 3 and 4 for the 2017 water year. These tables include some of the legacy information used to describe historic hydrologic conditions across Missouri. During water year
2017, three streamgages (06933500, 07057500 and 07068000) recorded peak streamflows that became the long-term period of record peak streamflows (table 3 ). The 7-day low flow for water year 2017 and the period of record, and the minimum daily mean streamflow for water year 2017 and for the period of record are presented for selected legacy information stations in table 4. The 7-day low flow and minimum daily mean flows recorded during water year 2017 were greater than historical records for the stations (table 4).

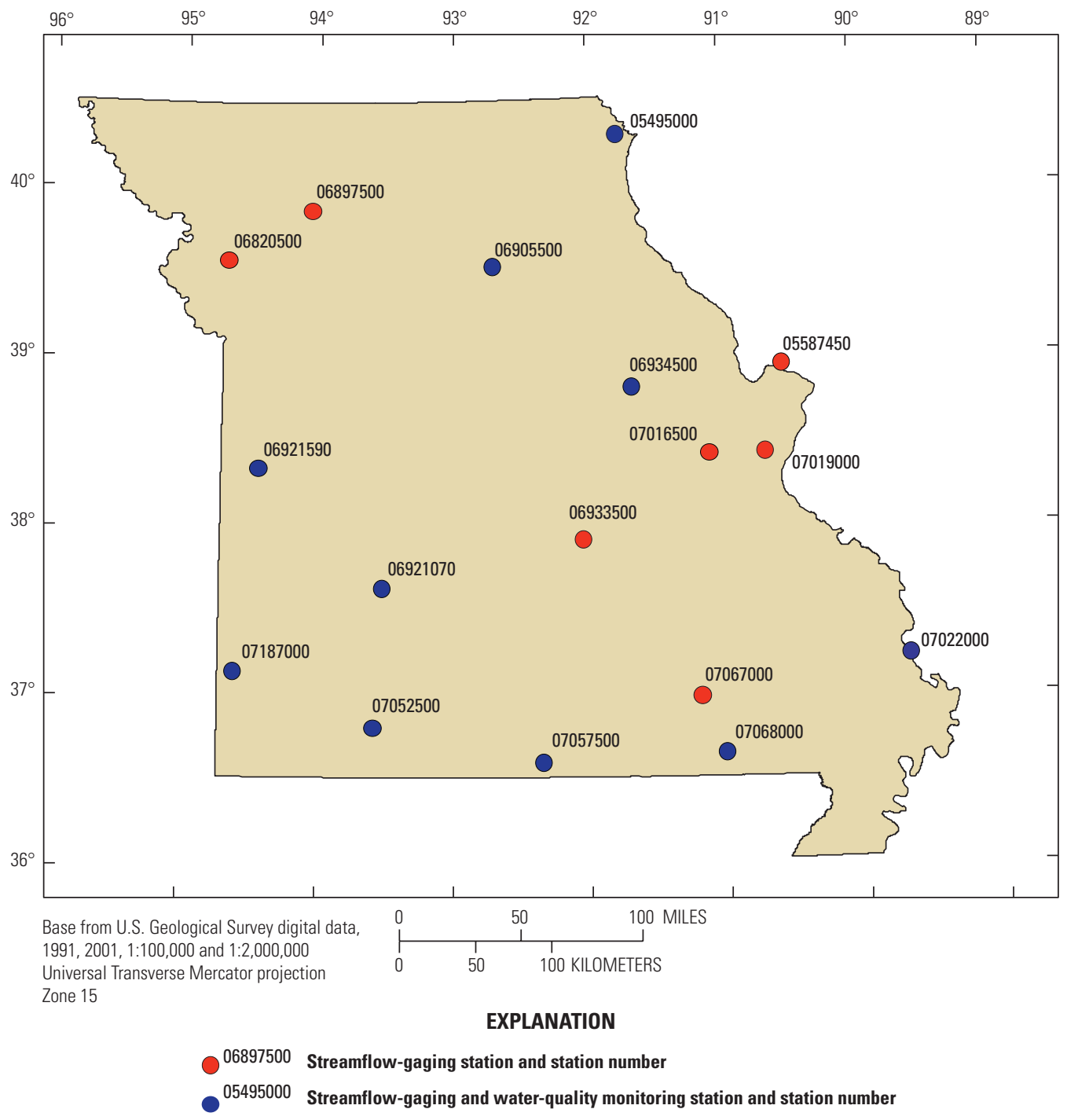

Figure 3. Location of selected streamflow-gaging stations used to provide a summary of hydrologic conditions within Missouri, water year 2017. Modified from Barr and Bartels (2018). 
Table 3. Peak streamflow for water year 2017 and periods of record for selected streamflow-gaging stations in Missouri.

[Water year 2017 is defined as October 1, 2016, through September 30, 2017. USGS, U.S. Geological Survey; fts, cubic foot per second]

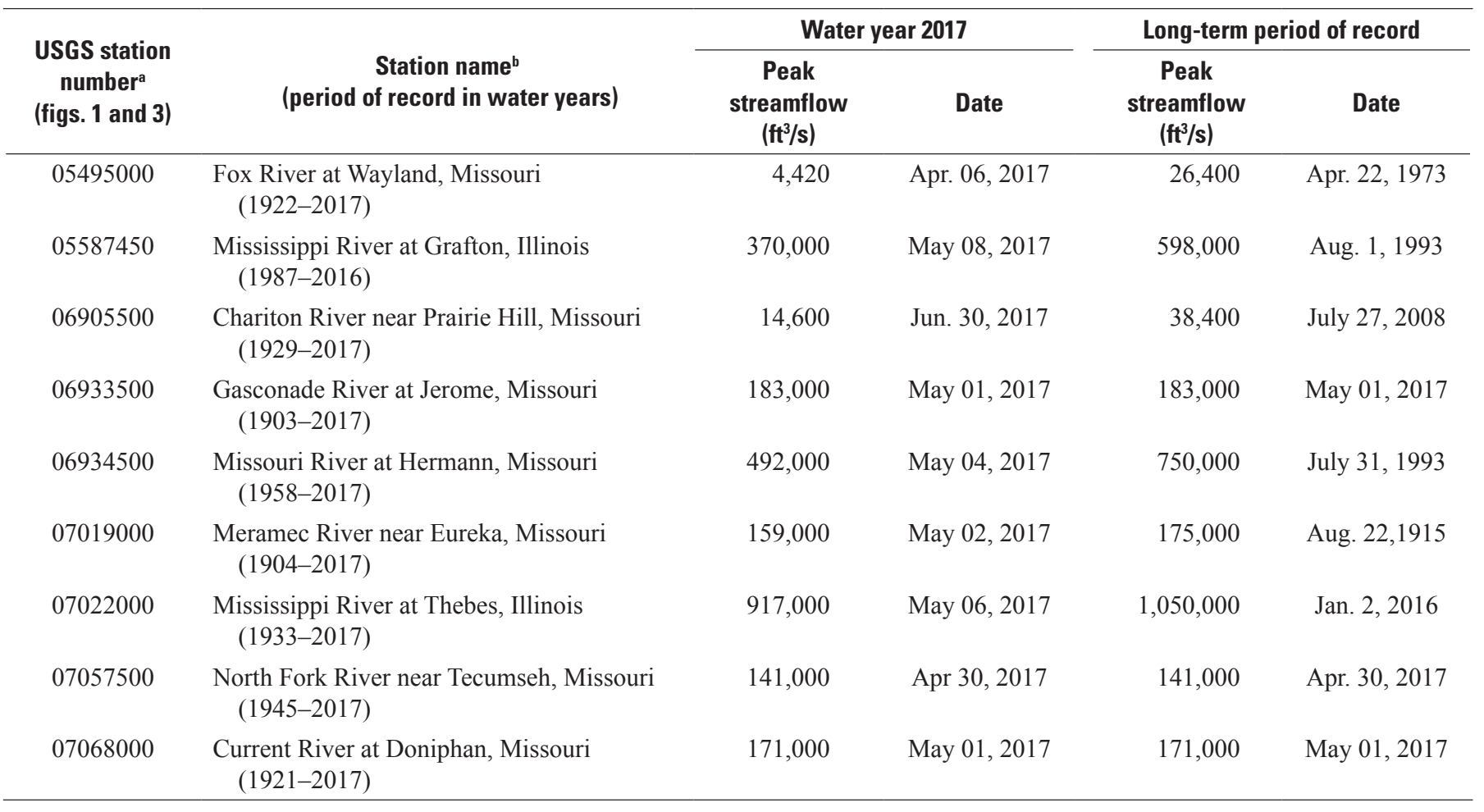

${ }^{\text {aS Stations }}$ 05587450, 06933500, and 07019000 are streamflow-gaging stations only and are not part of the Ambient Water-Quality Monitoring Network.

${ }^{\mathrm{b} S t a t i o n}$ names were obtained from the USGS National Water Information System database (U.S. Geological Survey, 2017).

Table 4. Seven-day low flow for water year 2017, period of record 7-day low flow, minimum daily mean streamflow for water year 2017, and period of record minimum daily mean streamflow for selected streamflow-gaging stations in Missouri.

[Water year 2017 defined as October 1, 2016, through September 30, 2017; USGS, U.S. Geological Survey; fts,s, cubic foot per second]

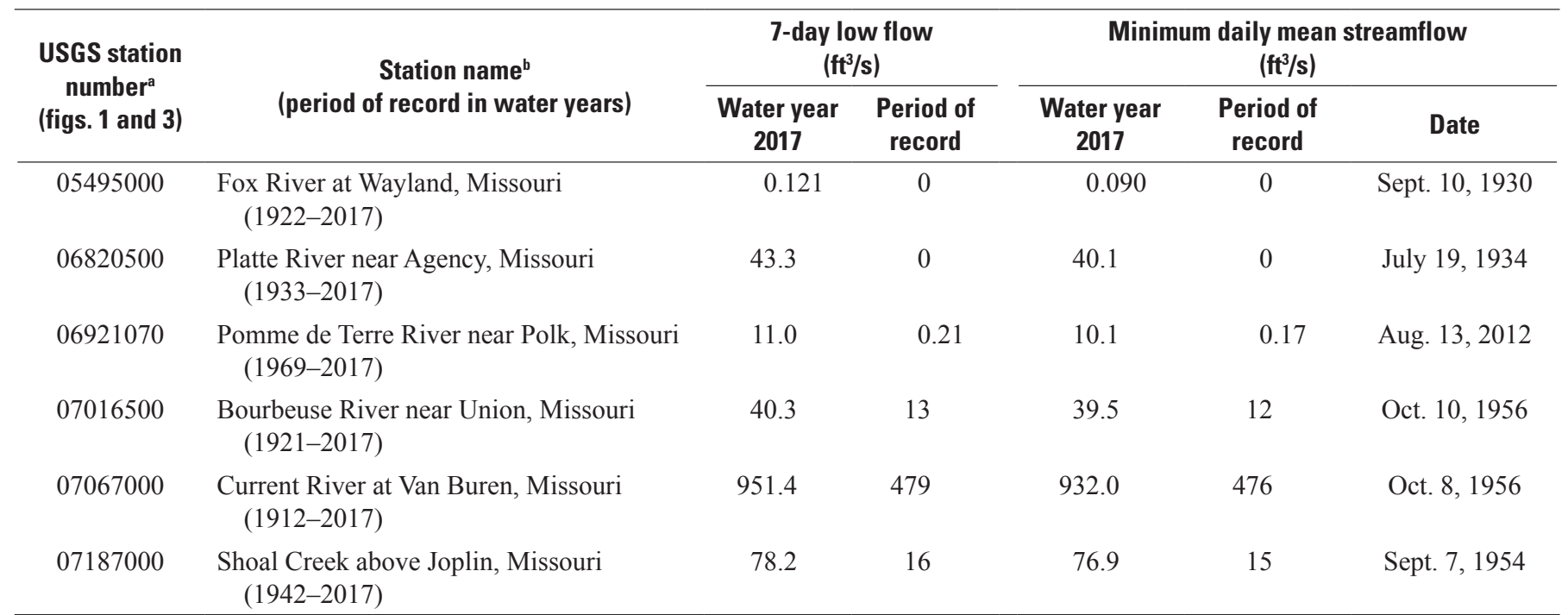

\footnotetext{
aStations 06820500,07016500 , and 07067000 are streamflow-gaging stations only and are not part of the Ambient Water-Quality Monitoring Network (AWQMN).
}

${ }^{b}$ Station names were obtained from the USGS National Water Information System database (U.S. Geological Survey, 2017). 


\section{Distribution, Concentration, and Detection Frequency of Selected Constituents}

This report presents results for dissolved oxygen, specific conductance, water temperature, suspended solids, suspended sediment, E. coli bacteria, fecal coliform bacteria, dissolved nitrate plus nitrite as nitrogen (hereinafter referred to as "nitrate plus nitrite"), total phosphorus, dissolved and total recoverable lead and zinc, and select pesticide compounds. Boxplots of these constituents are presented for 72 surfacewater stations by the different classifications (figs. 5-8). Pesticide data are presented from seven stations from six classes (fig. 9). For specific information on Missouri water-quality standards, refer to Missouri Department of Natural Resources (2016b).

\section{Physical Properties, Suspended-Solids Concentration, Suspended-Sediment Concentration, and Fecal Indicator Bacteria Density}

The physical properties analyzed for this report were dissolved oxygen, specific conductance, and water temperature. The median dissolved oxygen, in percent saturation, ranged from 78 to 107 percent (fig. 5). Samples from OSPL wi ag stations had the smallest median dissolved oxygen percent saturation values, whereas samples from URBAN stations had the largest median dissolved oxygen. Median specific conductance values varied substantially among the station classes, ranging from 110 microsiemens per centimeter at 25 degrees Celsius $\left(\mu \mathrm{S} / \mathrm{cm}\right.$ at $25^{\circ} \mathrm{C}$ ) at the OSPL pr station to $808 \mu \mathrm{S} / \mathrm{cm}$ at $25^{\circ} \mathrm{C}$ at the BRMOS station. Median water temperature ranged from 14.20 to $21.35^{\circ} \mathrm{C}$. The smallest median temperature was measured at the SPRING stations, and the largest was measured at DTPL wi ag stations. The interquartile range in water temperature at the SPRING stations was much smaller than for other station classes and types.

Suspended solids and suspended sediment are measures of the solid material suspended in the water column. These two measures are not considered directly comparable because of differences in collection and analytical techniques. Suspended-solids concentrations were determined for all station classes and types except BRMIT and BRMOH. Median suspended-solids concentrations ranged from the MRL (15) to 175 milligrams per liter (mg/L; fig. 5). Samples collected at the OZPL (SA fo/ag, SA wi fo/ag, and SP ag/fo), OSPL pr, DTPL ag, SPRING, MINING, and URBAN stations had median concentrations at the MRL $(15 \mathrm{mg} / \mathrm{L})$. The BRMOSJ station had the largest median suspended-solids concentration $(175 \mathrm{mg} / \mathrm{L})$. Suspended-sediment concentrations were determined at four Big River stations (fig. 5). Median suspended-sediment concentrations ranged from $106 \mathrm{mg} / \mathrm{L}$ at BRMIG to $318 \mathrm{mg} / \mathrm{L}$ at BRMOH (fig. 5).

Median E. coli and fecal coliform bacteria densities varied considerably among all station classes and types (fig. 6). Median E. coli bacteria densities ranged from 16 to $1,150 \mathrm{col}-$ onies per 100 milliliters of water. Fecal coliform bacteria density ranged from 32 to 1,450 colonies per 100 milliliters of water. The smallest median $E$. coli densities were in samples collected at SPRING stations and smallest median fecal coliform densities were in samples collected from OZPLSA wi fo/ag stations. The largest median E. coli and fecal coliform densities were in samples collected at the BRMOS station (fig. 6).

\section{Dissolved Nitrate plus Nitrite and Total Phosphorus Concentrations}

Samples were collected at all stations for the analysis of nutrients, including dissolved nitrate plus nitrite and total phosphorus. Median dissolved nitrate plus nitrite and total phosphorus concentrations varied considerably among all station classes and types (fig. 7), ranging from the LT-MDL (0.04) to $4.00 \mathrm{mg} / \mathrm{L}$ for dissolved nitrate plus nitrite and from the LT-MDL (0.02) to $0.35 \mathrm{mg} / \mathrm{L}$ for total phosphorus. The smallest median dissolved nitrate plus nitrite concentrations were computed at the OSPL pr and DTPL ag stations. The largest concentrations were computed in samples collected at the URBAN station (fig. 7). The smallest median total phosphorus concentrations were computed at the OZPLSA (fo/ag and wi fo/ag) and SPRING stations, all of which had median values equal to the LT-MDL $(0.02 \mathrm{mg} / \mathrm{L})$. The largest median concentration was at the BRMIT station (fig. 7).

\section{Dissolved and Total Recoverable Lead and Zinc Concentrations}

No dissolved or total recoverable lead and zinc samples were collected at the BRMIT and BRMOH stations. Median concentration ranges were from the LT-MDL of 0.020 to 0.511 micrograms per liter $(\mu \mathrm{g} / \mathrm{L})$ for dissolved lead, 0.1150 to $8.8 \mu \mathrm{g} / \mathrm{L}$ for total recoverable lead, the LT-MDL of 2.0 to $20.2 \mu \mathrm{g} / \mathrm{L}$ for dissolved zinc, and the LT-MDL of 2.0 to $35.0 \mu \mathrm{g} / \mathrm{L}$ for total recoverable zinc (fig. 8).

The smallest median concentrations of dissolved lead were at the LT-MDL $(0.02 \mu \mathrm{g} / \mathrm{L})$ in samples collected at the BRMIG, OZPLSA (fo/ag, wi fo/ag), OZPLSP ag/fo, and SPRING stations. Samples from the MINING stations had the largest median concentration (fig. 8). The smallest median concentrations of total recoverable lead were at the OZPLSP $\mathrm{ag} /$ fo stations. The largest median total recoverable lead concentration was at the URBAN wi station. Median dissolved zinc concentrations were at the LT-MDL $(2.0 \mu \mathrm{g} / \mathrm{L})$ for all stations, except the BRMOSJ, BRMOS, OZPLSP ag/fo, OSPL pr, SPRING, MINING, and URBAN stations. URBAN 
05495000 Fox River at Wayland, Missouri'
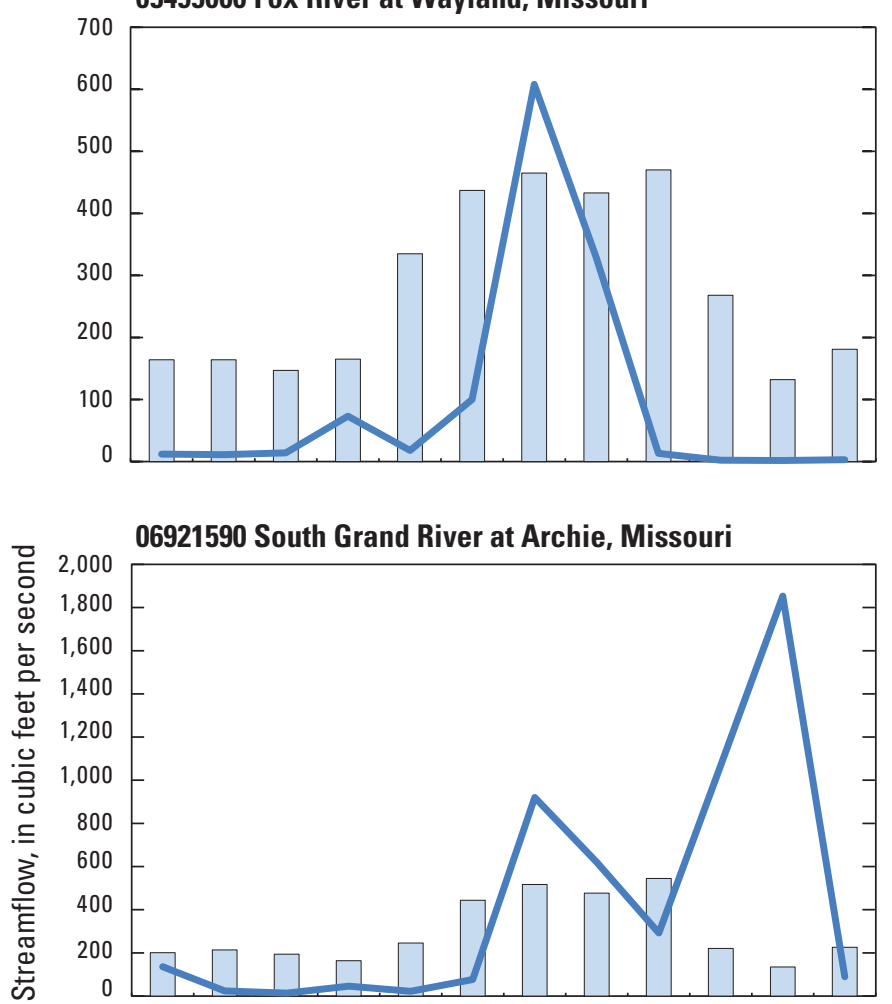

07052500 James River at Galena, Missouri'
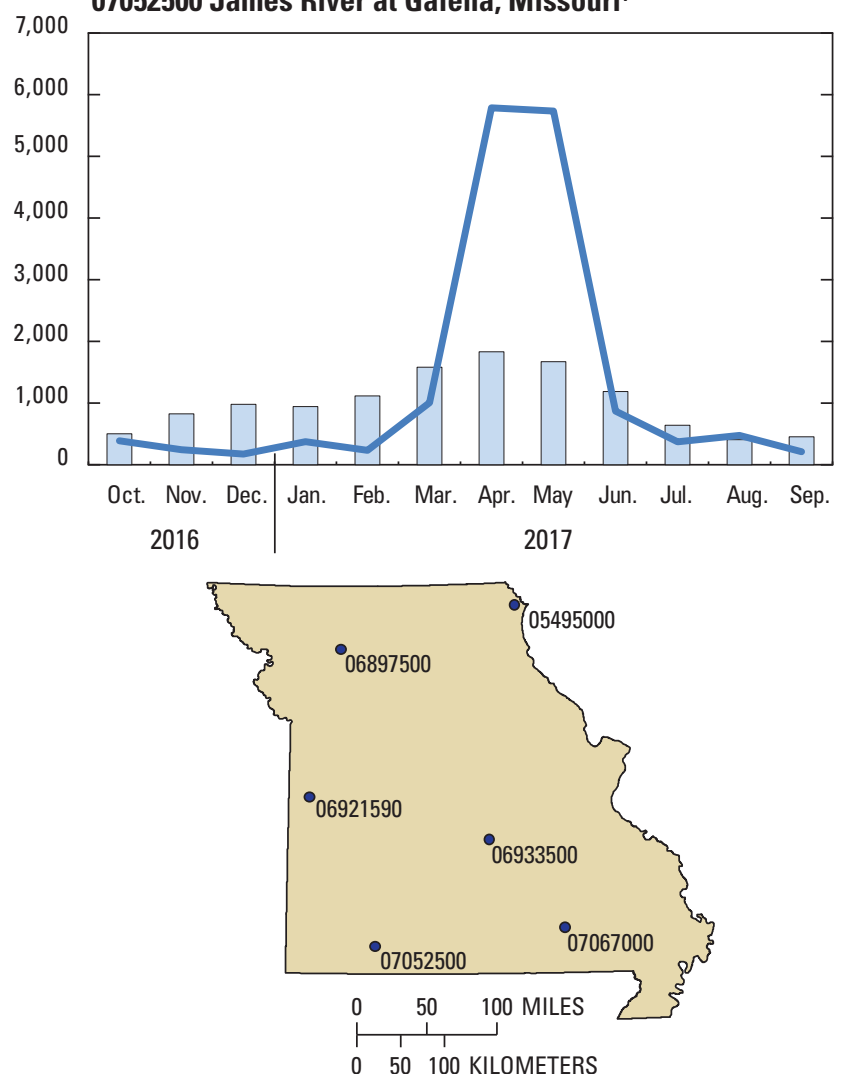

06897500 Grand River near Gallatin, Missouri
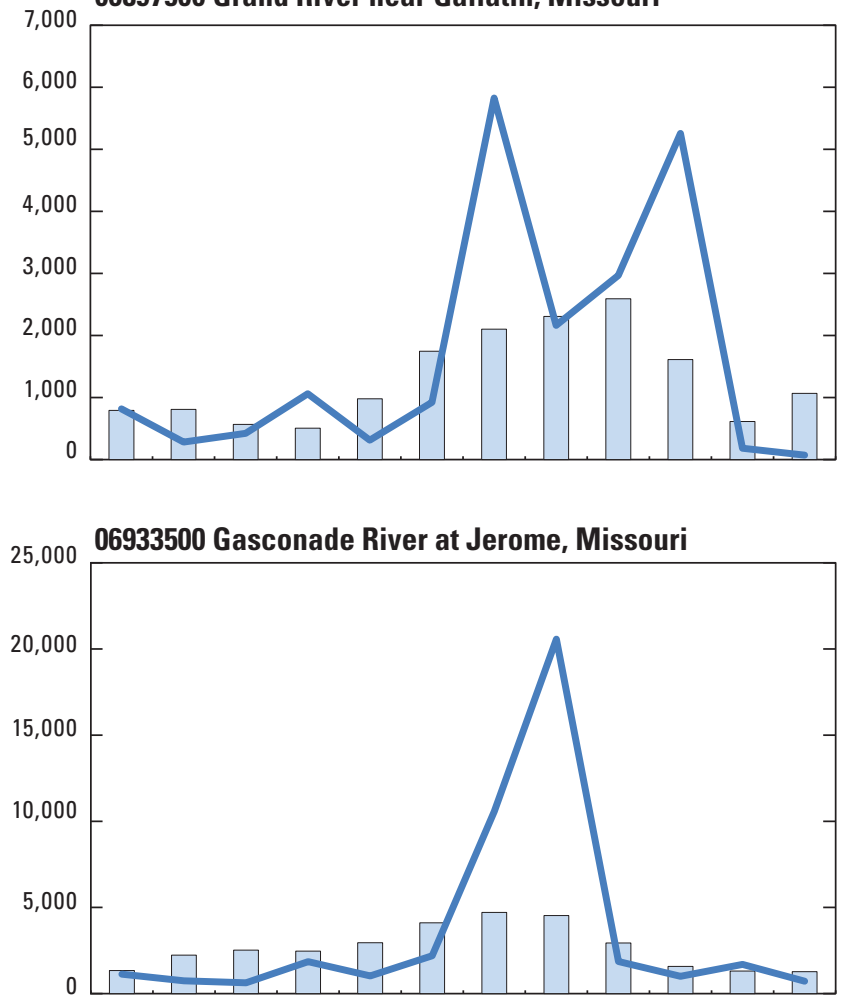

07067000 Current River at Van Buren, Missouri

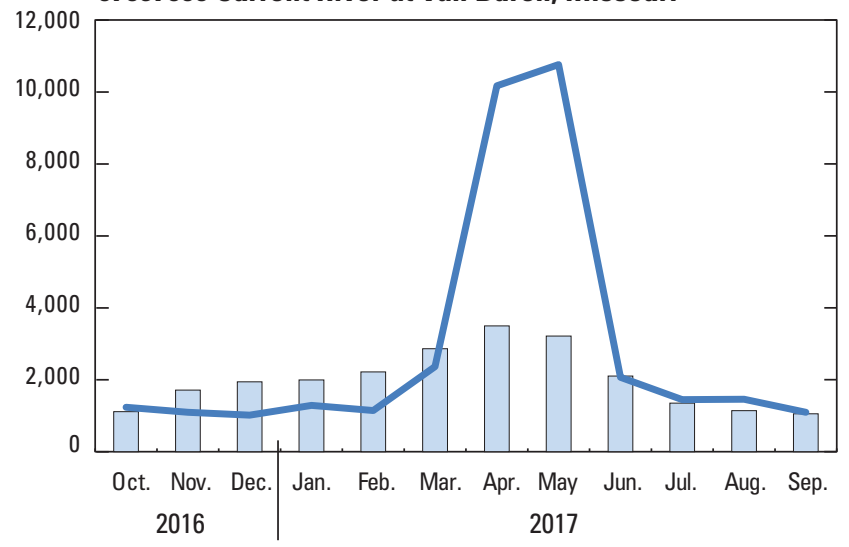

Month

\section{EXPLANATION}

Long-term mean monthly streamflow

Water year 2017 monthly mean streamflow

${ }^{1}$ Station is part of the Ambient Water-Quality Monitoring Network

Figure 4. Monthly mean streamflow for water year 2017 and long-term mean monthly streamflow at six representative streamflowgaging stations in Missouri. 

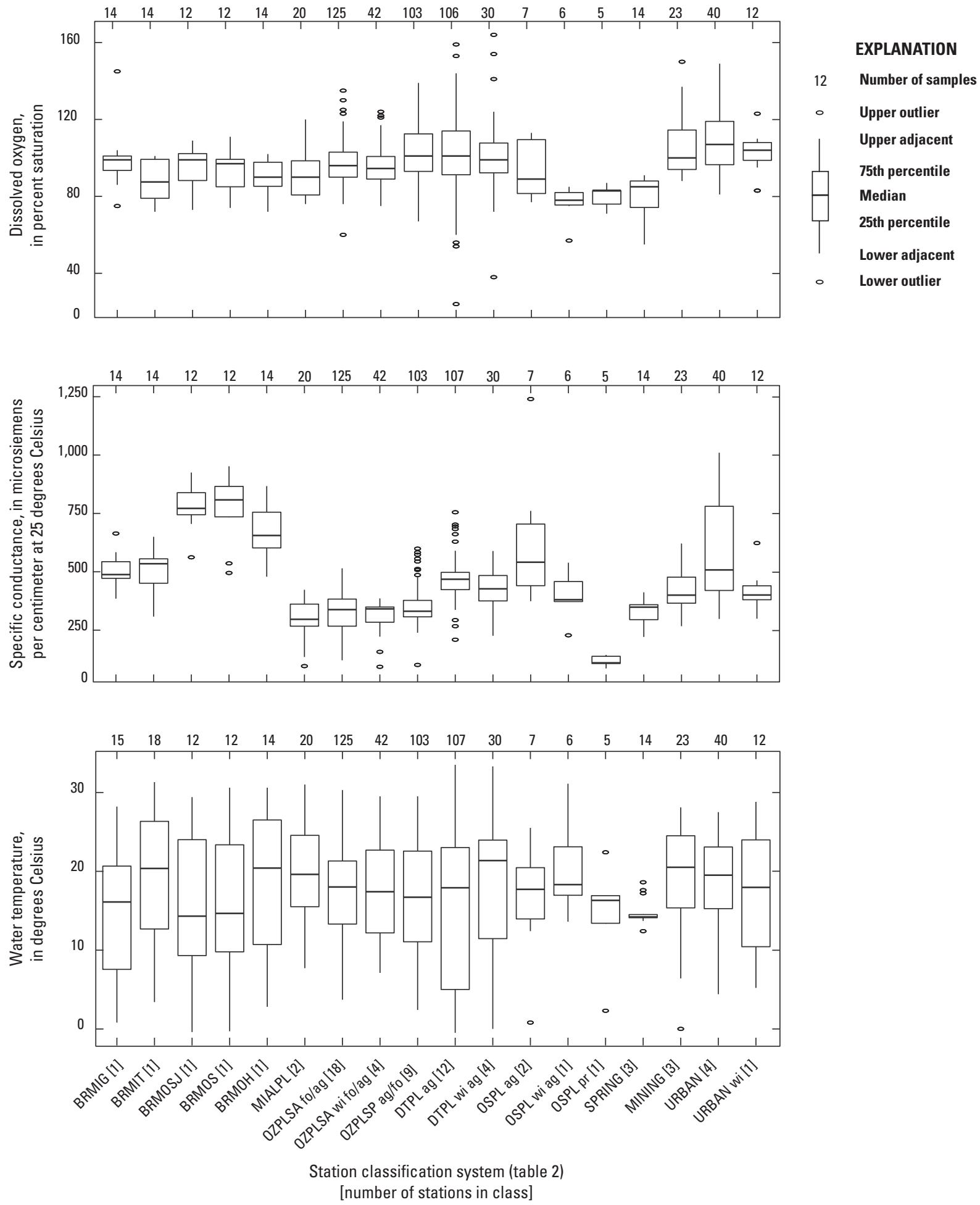

Figure 5. Distribution of physical properties, suspended-solids concentrations, and suspended-sediment concentrations from surface-water quality stations in Missouri, water year 2017. 

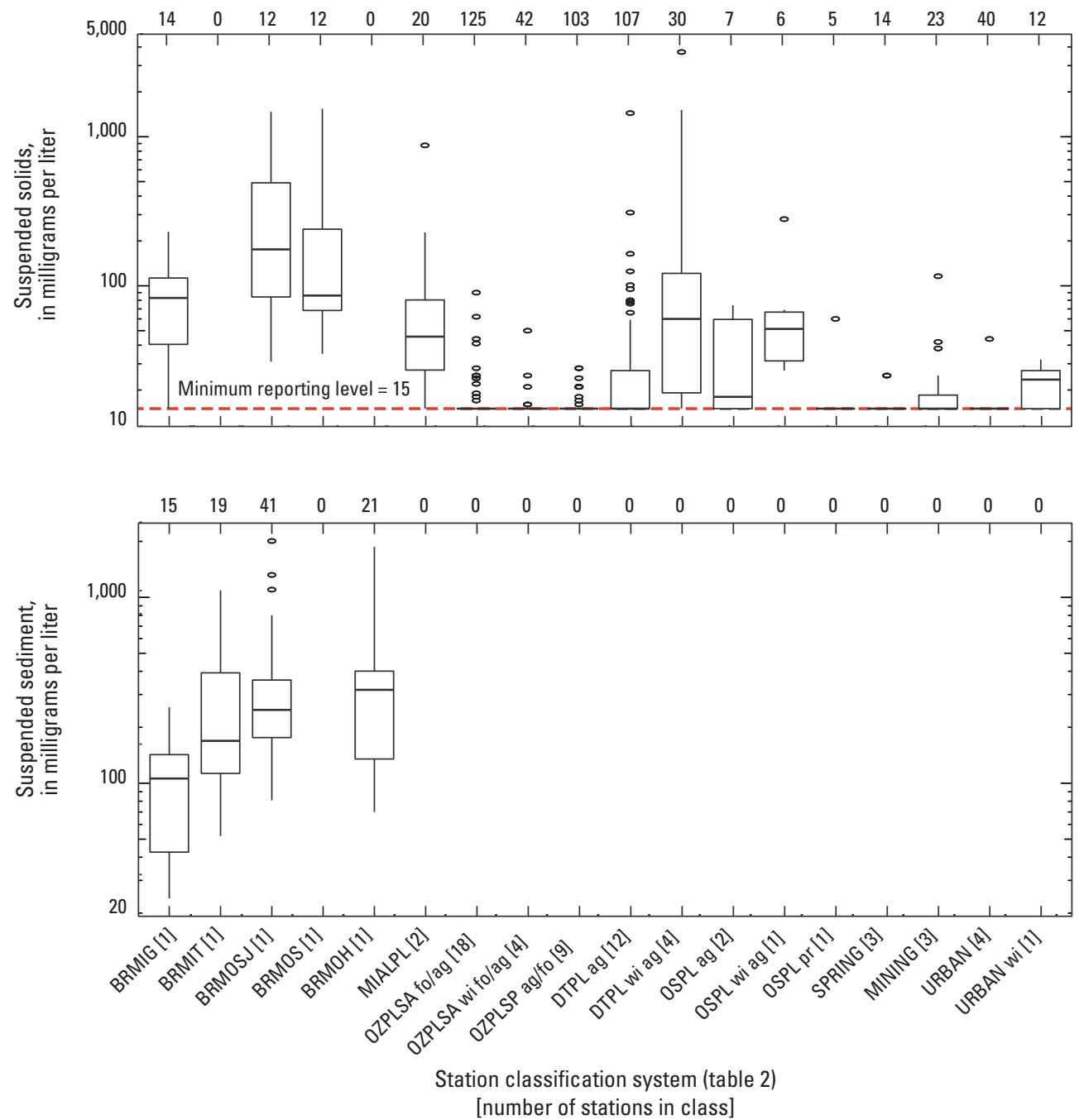

EXPLANATION

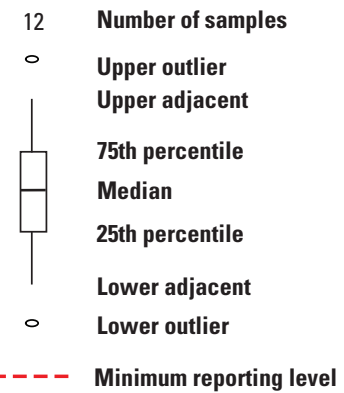

Figure 5. Distribution of physical properties, suspended-solids concentrations, and suspended-sediment concentrations from surface-water quality stations in Missouri, water year 2017.-Continued 

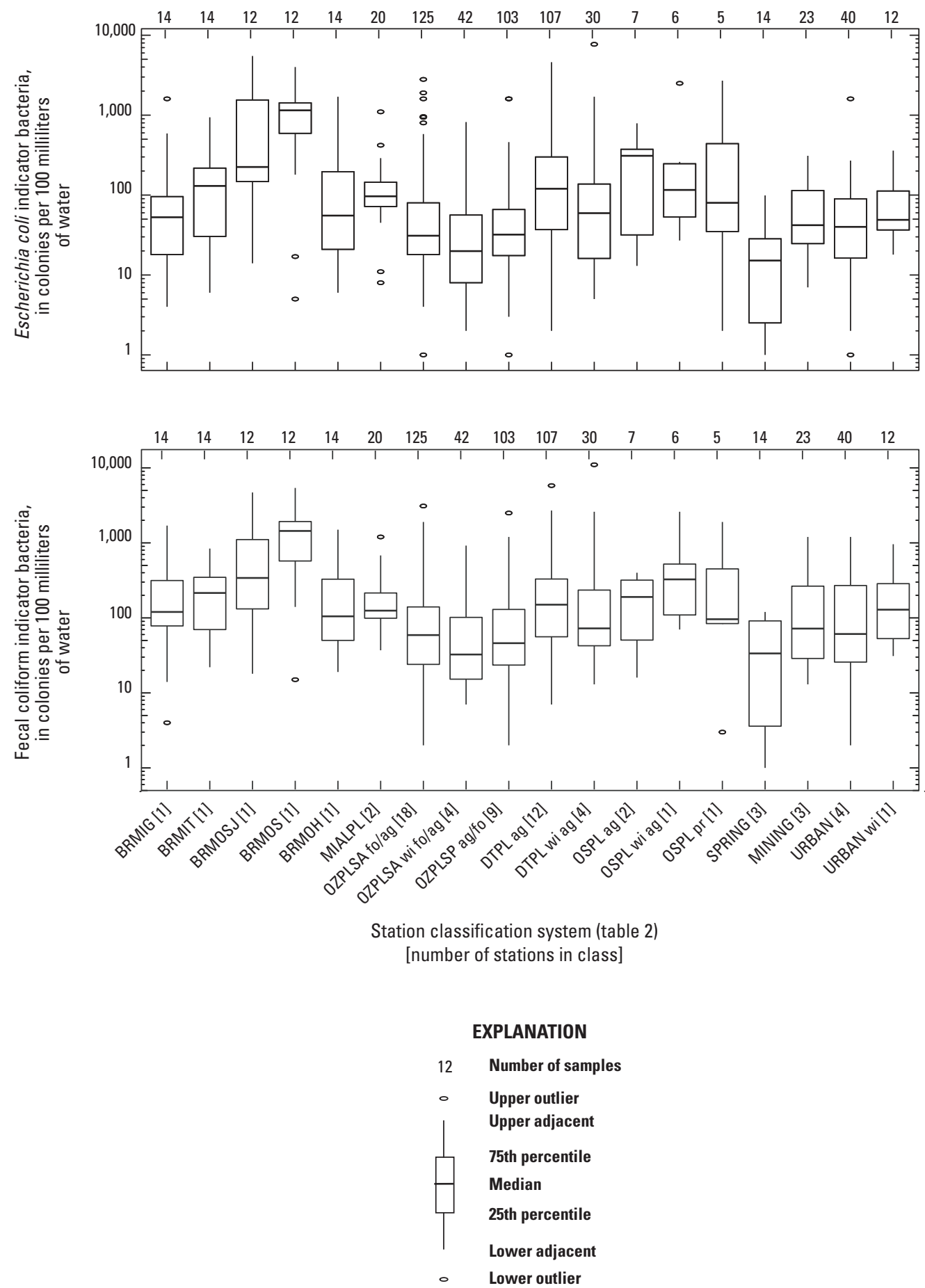

Figure 6. Distribution of fecal indicator bacteria density in samples from surfacewater quality stations in Missouri, water year 2017. 

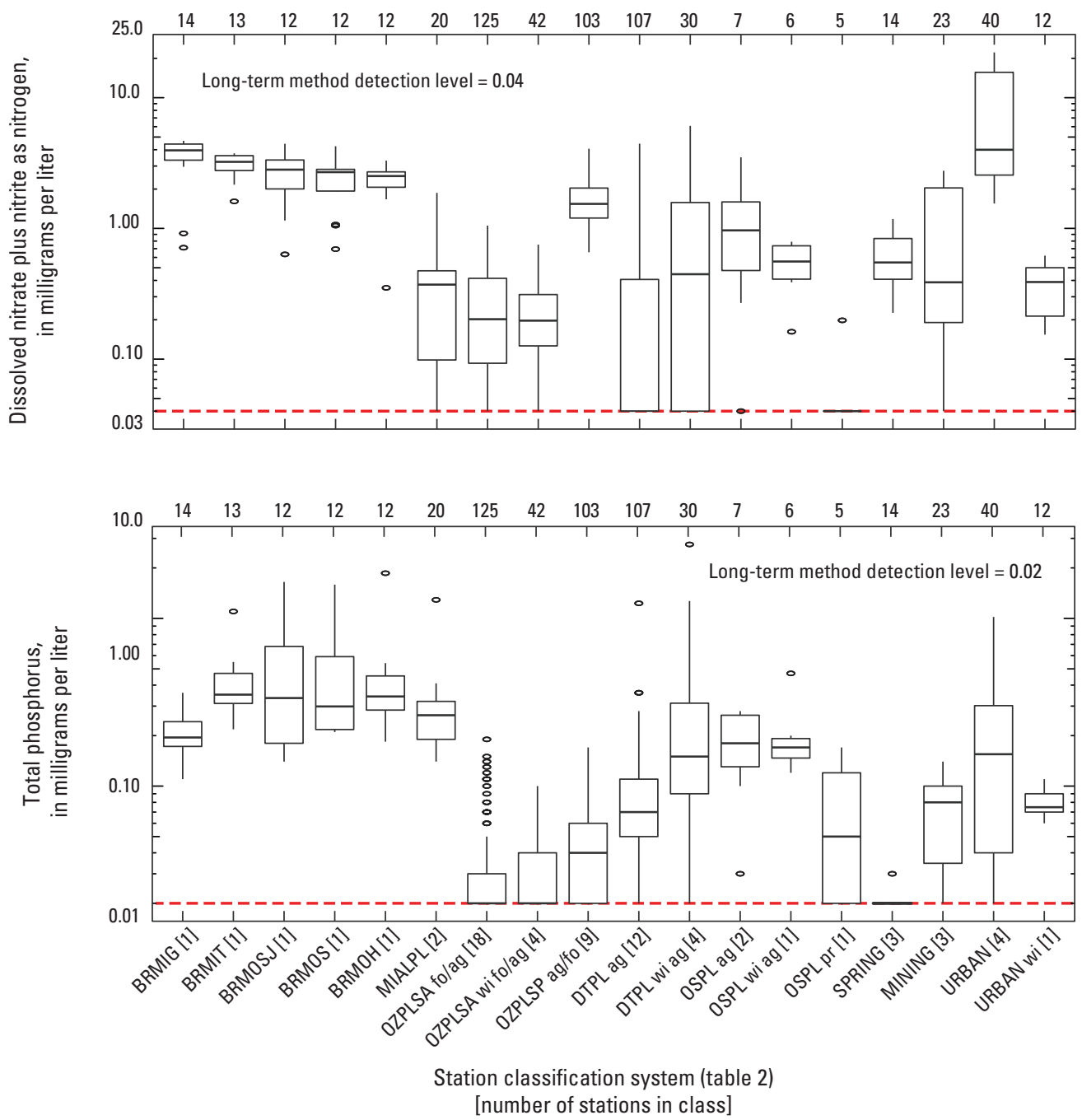

\section{EXPLANATION}

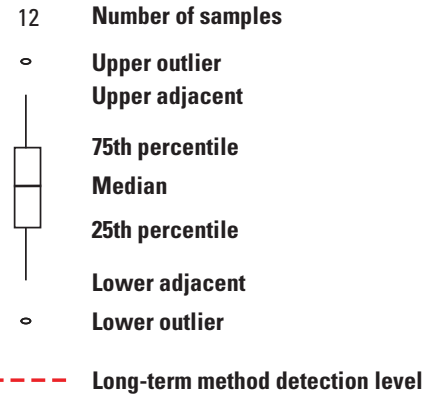

Figure 7. Distribution of dissolved nitrate plus nitrite as nitrogen and total phosphorus concentrations in samples from surface-water quality stations in Missouri, water year 2017. 

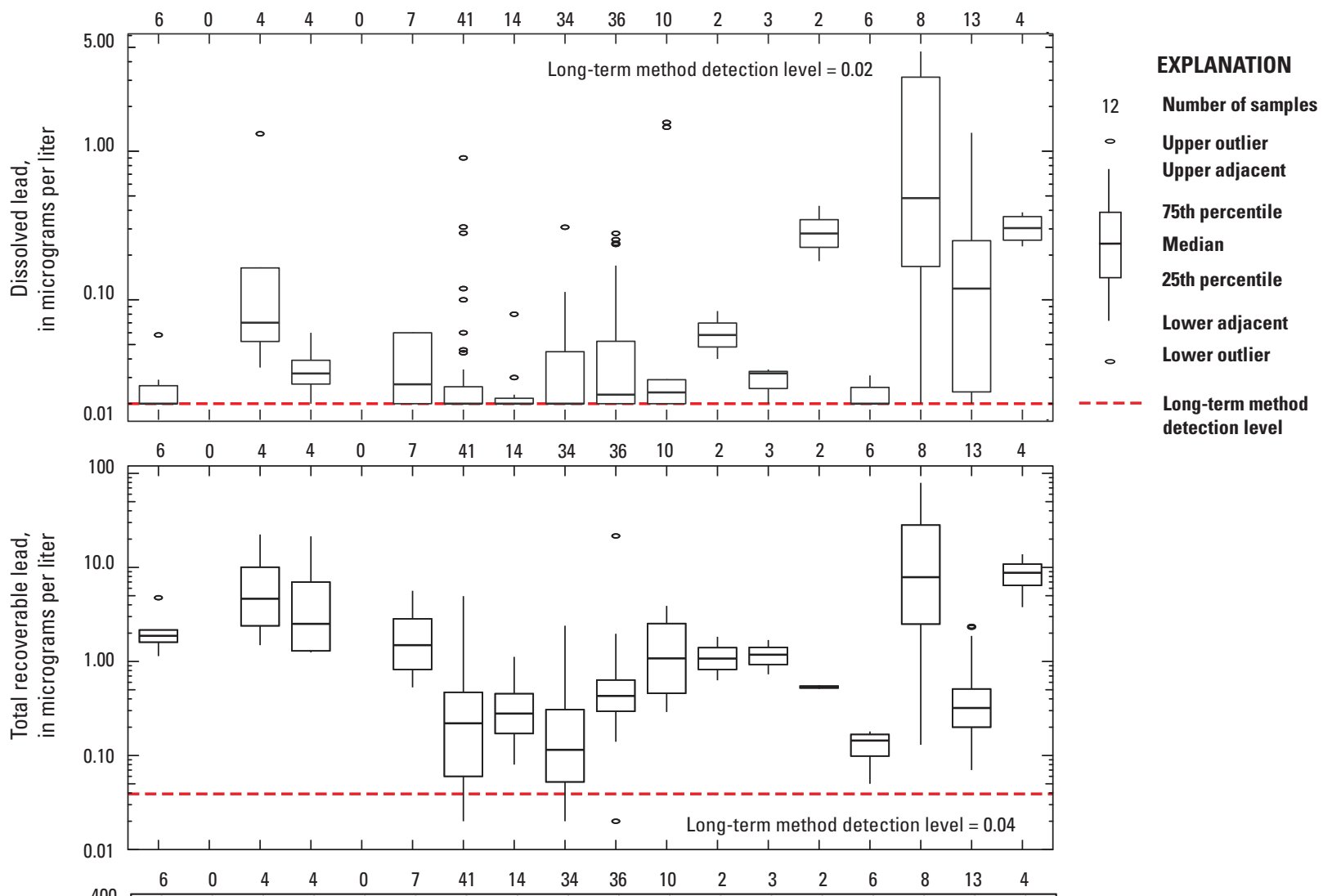

detection level
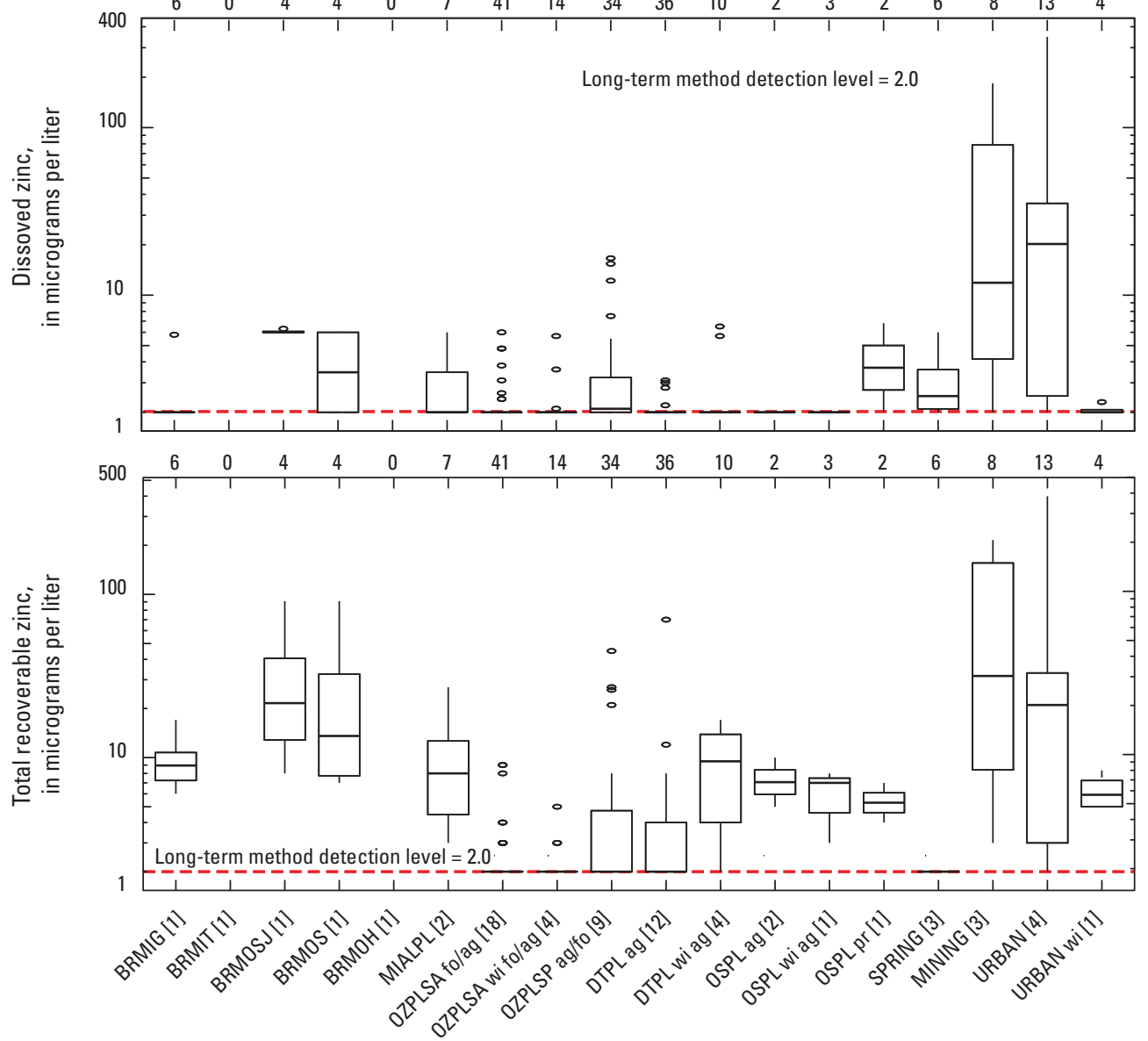

Station classification system (table 2) [number of stations in class]

Figure 8. Distribution of dissolved and total recoverable lead and zinc concentrations from surface-water quality stations in Missouri, water year 2017 

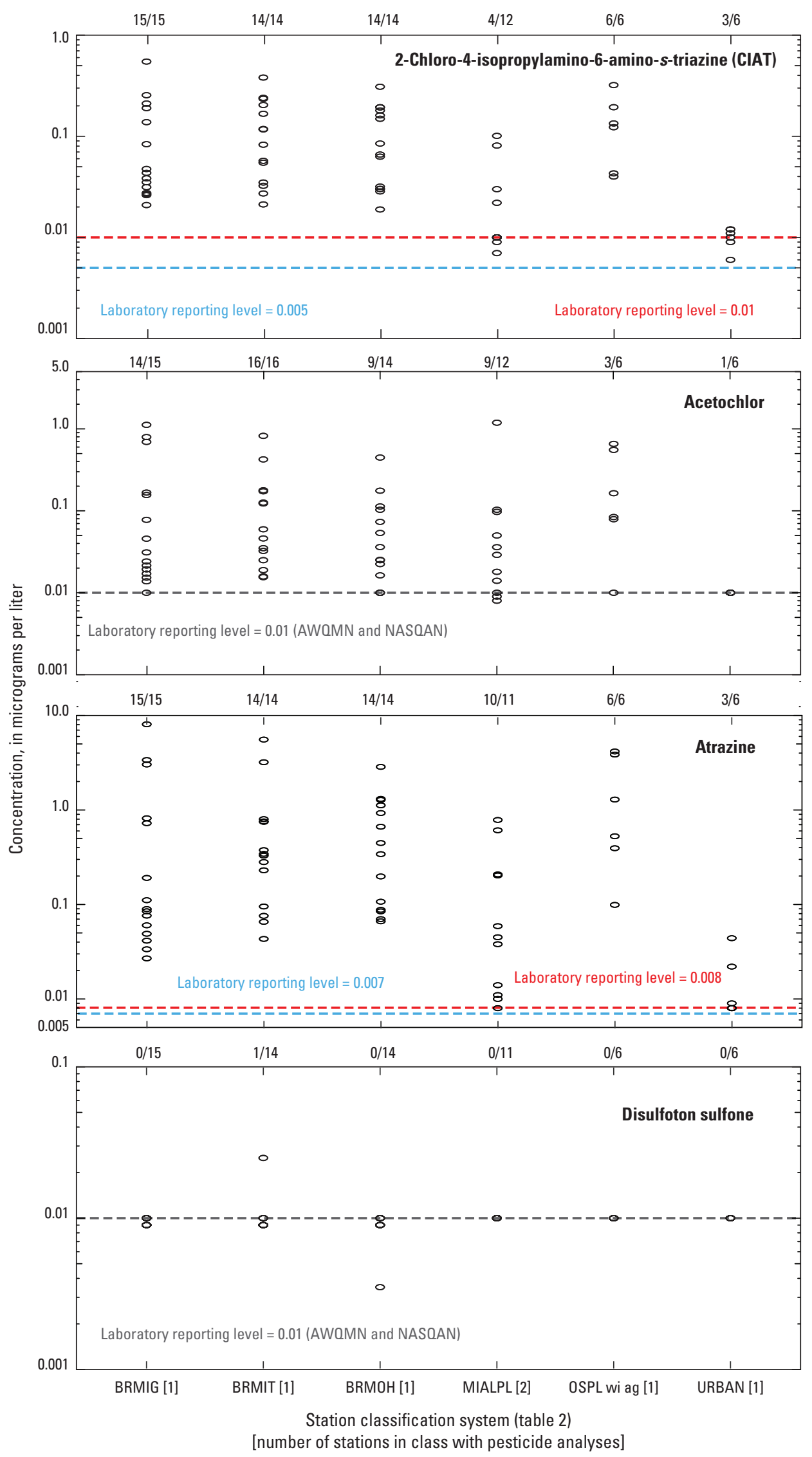

Figure 9. Detection of selected pesticides in samples from selected surface-water quality stations, water year 2017.

\section{EXPLANATION}

Laboratory reporting level (LRL)—Ambient Water-Quality Monitoring Network (AWQMN) collections. Concentrations less than LRL are estimated

Laboratory reporting level (LRL)-U.S. Geological Survey National Stream Quality Assessment Network (NASQAN) collections. Concentrations less than

LRL are estimated

- Sample

12/12 Number of detections/total number of samples 


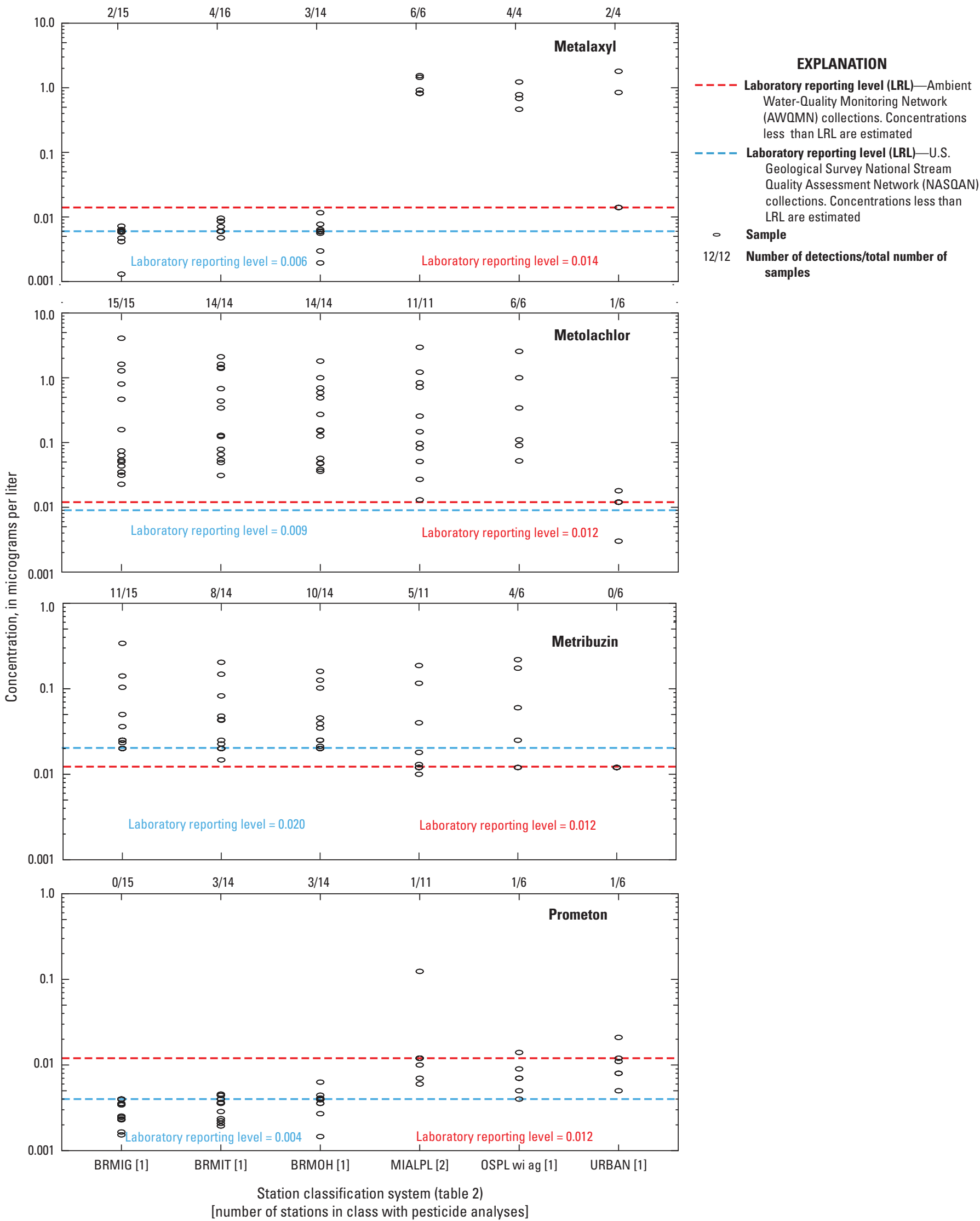

Figure 9. Detection of selected pesticides in samples from selected surface-water quality stations, water year 2017.-Continued 


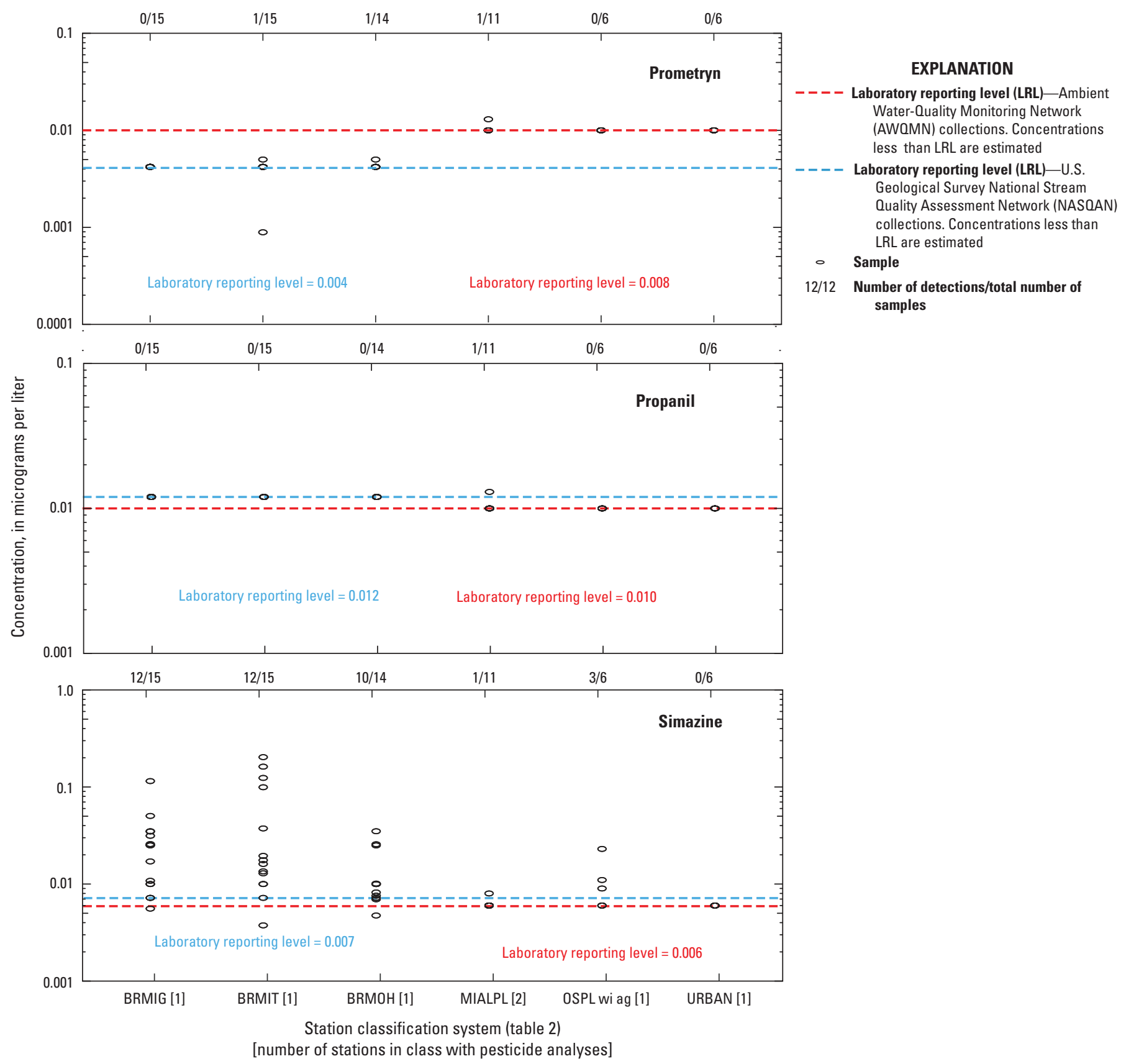

Figure 9. Detection of selected pesticides in samples from selected surface-water quality stations, water year 2017.-Continued 


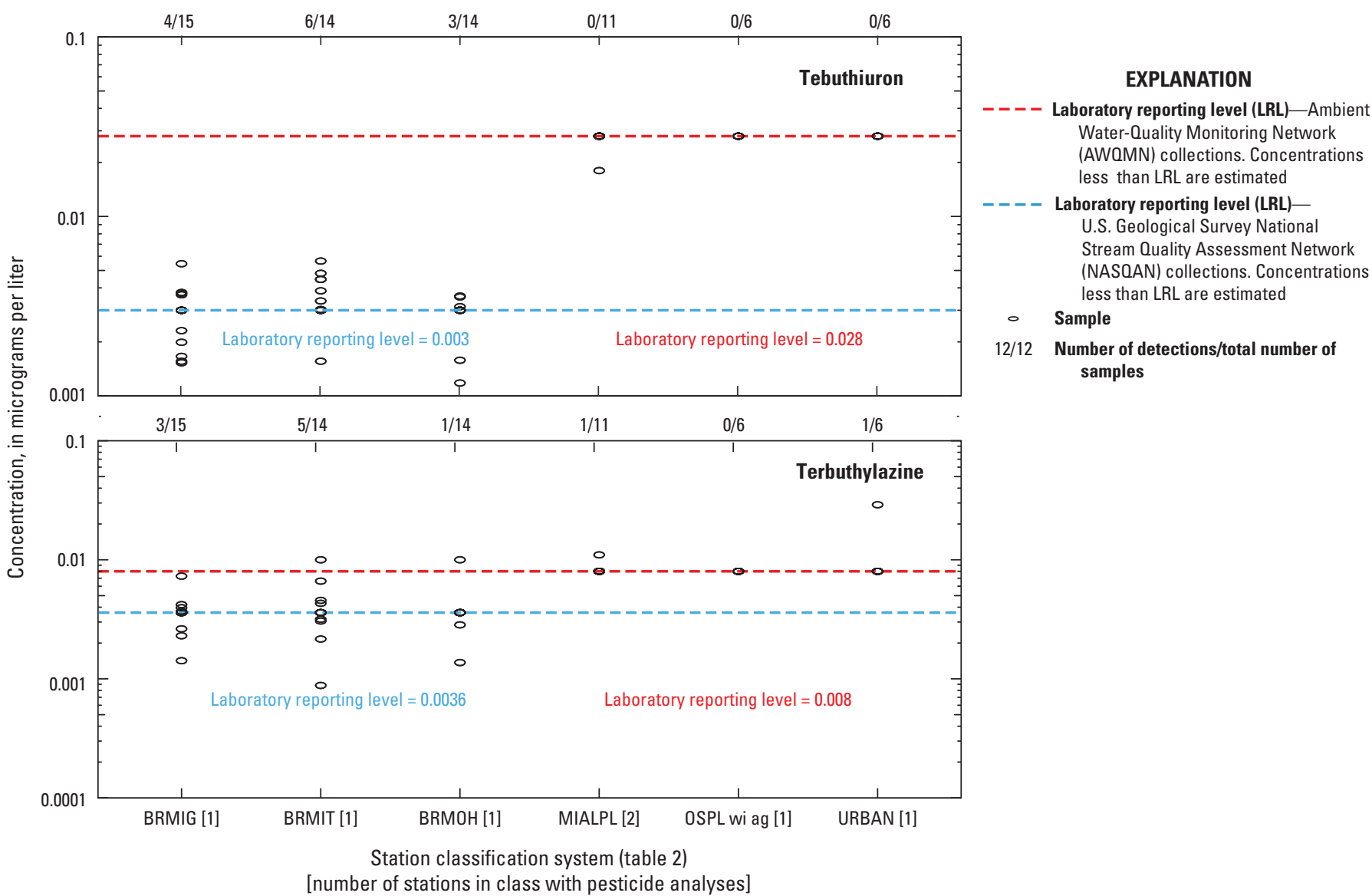

Figure 9. Detection of selected pesticides in samples from selected surface-water quality stations, water year 2017.-Continued

stations had the largest median concentration of dissolved zinc. The smallest median concentrations of total recoverable zinc were at the LT-MDL of $2.0 \mu \mathrm{g} / \mathrm{L}$ at the OZPLSA (fo/ag and wi fo/ag), OZPLSP ag/fo, DTPL ag, and SPRING stations. The largest median concentration of total recoverable zinc was at the MINING stations $(35 \mu \mathrm{g} / \mathrm{L})$.

\section{Selected Pesticide Concentrations and Detection Frequencies}

Samples collected for the analysis of dissolved pesticide compounds during the 2017 water year are presented in this report for seven stations. The AWQMN and NASQAN pesticide programs use different analytical methods and the detection limits are somewhat different. Samples from four AQWMN stations were analyzed for a suite of 85 pesticides (both stations in the MIALPL, one OSPL wi ag station, and one URBAN station; fig. 9). An expanded list of 228 pesticides were analyzed in samples from three Big River stations (BRMIG, BRMIT, and BRMOH) as part of the NASQAN program.
Thirteen pesticide compounds were detected above their LRL in at least one sample during the 2017 water year. The thirteen constituents are 2-chloro-4-isopropylamino-6-amino$s$-triazine (more commonly referred to as CIAT, a degradation product of atrazine), acetochlor, atrazine, disulfoton sulfone, metalaxyl, metolachlor, metribuzin, prometon, prometryn, propanil, simazine, tebuthiuron, and terbuthylazine (fig. 9). The most frequently detected pesticides were CIAT (detected in 83 percent of the samples collected), acetochlor (75-percent detection), atrazine (94-percent detection), and metolachlor (92-percent detection). Metribuzin and simazine were detected in more than half of the samples analyzed (58 and 57 percent, respectively). The concentrations for pesticide compounds shown in figure 9 were less than $1.00 \mu \mathrm{g} / \mathrm{L}$ except acetochlor, atrazine, metalaxyl, and metolachlor. Of the three Big River stations, BRMIT had the greatest percentage of detections (52 percent of samples collected had detections greater that the LRL). Of the four AWQMN monitoring stations, the OSPL wi ag station had the greatest percentage of detections (43 percent of all samples had detections greater than the LRL). 


\section{Summary}

The U.S. Geological Survey (USGS), in cooperation with the Missouri Department of Natural Resources (MDNR), collects surface-water quality data in Missouri each water year (October 1 through September 30). These data, stored and maintained in the USGS National Water Information System database, are collected as part of the Missouri Ambient Water-Quality Monitoring Network (AWQMN) and constitute a permanent, accessible source of representative, reliable, impartial, and timely information for developing an enhanced understanding of the State's water resources. In addition to the AWQMN, the USGS also collects data at two USGS National Stream Quality Assessment Network (NASQAN) stations and, in cooperation with the U.S. Army Corps of Engineers, routinely collects suspended-sediment concentration data and various particle-size distribution data on the Missouri and Mississippi Rivers. These data assist in understanding long-term trends in the concentration of selected constituents as well as sediment transport and navigable channel assessments along the large rivers.

Surface-water quality data collected during water year 2017 at 72 stations (70 AWQMN and 2 NASQAN stations) are summarized in this report, among which are 4 stations with suspended-sediment data collected in cooperation with the U.S. Army Corps of Engineers. Stations were classified corresponding to physiographic province, primary land use, or unique station types. The annual summary of selected constituents provides Missouri Department of Natural Resources with current information to assess the quality of surface water within the State and ensure the objectives of the AWQMN are being met. The data collected also provide support for the design, implementation, and evaluation of preventive and remediation programs.

The analyses presented in this report are for dissolved oxygen, specific conductance, water temperature, suspended solids, suspended sediment, Escherichia coli bacteria, fecal coliform bacteria, dissolved nitrate plus nitrite as nitrogen, total phosphorus, and dissolved and total recoverable lead and zinc. Plots of the concentrations of these constituents are presented by the different station classes. In addition, 13 pesticide compound concentrations are presented for seven stations. A comparison of 2017 streamflow data to long-term streamflow, a summary of hydrologic conditions in the State including peak streamflows, monthly mean streamflows, and 7-day low flows at selected stations also are presented.

\section{References Cited}

Barr, M.N., 2010, Quality of surface water in Missouri, water year 2009: U.S. Geological Survey Open-File Report 2010-1233, 22 p., accessed October 17, 2017, at https://pubs.usgs.gov/of/2010/1233/.
Barr, M.N., 2011, Quality of surface water in Missouri, water year 2010: U.S. Geological Survey Data Series 636, 21 p., accessed October 17, 2017, at https://pubs.usgs.gov/ds/636/.

Barr, M.N., 2013, Quality of surface water in Missouri, water year 2011: U.S. Geological Survey Data Series 734, 22 p., accessed October 17, 2017, at https://pubs.usgs.gov/ds/734/.

Barr, M.N., 2014, Quality of surface water in Missouri, water year 2012: U.S. Geological Survey Data Series 818, 24 p., accessed October 17, 2017, at https://doi.org/10.3133/ ds818.

Barr, M.N., 2015, Quality of surface water in Missouri, water year 2014: U.S. Geological Survey Data Series 971, 22 p., accessed October 17, 2017, at http://dx.doi.org/10.3133/ ds971.

Barr, M.N., and Bartels, K.A., 2018, Quality of surface water in Missouri, water year 2016: U.S. Geological Survey Data Series 1086, 25 p., accessed August 20, 2018, at https://doi.org/10.3133/ds1086.

Barr, M.N., and Davis, J.V., 2010, Surface-water quality conditions and long-term trends at selected sites within the ambient water-quality monitoring network in Missouri, water years 1993-2008: U.S. Geological Survey Scientific Investigations Report 2010-5078, 42 p. [Also available at https://doi.org/10.3133/sir20105078.]

Barr, M.N., and Heimann, D.C., 2016, Quality of surface water in Missouri, water year 2015: U.S. Geological Survey Data Series 1023, 22 p., accessed October 17, 2017, at https://doi.org/10.3133/ds1023.

Barr, M.N., and Schneider, R.E., 2014, Quality of surface water in Missouri, water year 2013: U.S. Geological Survey Data Series 886, 21 p., accessed October 17, 2017, at https://pubs.usgs.gov/ds/0886/.

Childress, C.J.O., Foreman, W.T., Connor, B.F., and Maloney, T.J., 1999, New reporting procedures based on longterm method detection levels and some considerations for interpretations of water-quality data provided by the U.S. Geological Survey National Water Quality Laboratory: U.S. Geological Survey Open-File Report 99-193, 19 p. [Also available at https://doi.org/10.3133/ofr99193.]

Edwards, T.K., and Glysson, G.D., 1999, Field methods for measurement of fluvial sediment: U.S. Geological Survey Techniques of Water-Resources Investigations, book 3, chap. C2, 89 p., accessed October 24, 2017, at https://pubs.usgs.gov/twri/twri3-c2/.

Fenneman, N.M., 1938, Physiography of eastern United States: New York, McGraw-Hill Book Co., Inc., 689 p. 
Fishman, M.J., ed., 1993, Methods of analysis by the U.S. Geological Survey National Water Quality Laboratory-Determination of inorganic and organic constituents in water and fluvial sediments: U.S. Geological Survey Open-File Report 93-125, 217 p. [Also available at https://pubs.er.usgs.gov/publication/ofr93125.]

Garbarino, J.R., Kanagy, L.K., and Cree, M.E., 2006, Determination of elements in natural-water, biota, sediment and soil samples using collision/reaction cell inductively coupled plasma-mass spectrometry: U.S. Geological Survey Techniques and Methods, book 5, chap. B1, 88 p. [Also available at https://pubs.usgs.gov/tm/2006/tm5b1/.]

Guy, H.P., 1969, Laboratory theory and methods for sediment analysis: U.S. Geological Survey Techniques of WaterResources Investigations, book 5, chap. C1, 64 p., accessed November 21, 2017, at https://pubs.usgs.gov/twri/twri5c1/.

Helsel, D.R., and Hirsch, R.M., 2002, Statistical methods in water resources: U.S. Geological Survey Techniques of Water-Resources Investigations, book 4, chap. A3, 522 p., accessed November 13, 2017, at https://pubs.usgs.gov/twri/ twri4a3/.

Missouri Department of Natural Resources, 2016a, Missouri integrated water quality report and section 303(d) list, 2016: Jefferson City, Mo., Missouri Department of Natural Resources, Water Protection Program, accessed January 21, 2018, at https://nr.mo.gov/env/wpp/ waterquality/303d/303d.htm.

Missouri Department of Natural Resources, 2016b, Water quality, chap. 7 of Rules of Department of Natural Resources-Division 20-Clean Water Commission: Jefferson City, Mo., Missouri Department of Natural Resources, Clean Water Commission, p. 54-131, accessed January 21, 2018, at https://s1.sos.mo.gov/cmsimages/adrules/csr/ current/10csr/10c20-7a.pdf.

Myers, D.N., Stoeckel, D.M., Bushon, R.N., Francy, D.S., and Brady, A.M.G., 2014, Fecal indicator bacteria (ver. 2.1): U.S. Geological Survey Techniques of Water-Resources Investigations, book 9, chap. A7, sec. 7.1, accessed October 26, 2017, at https://pubs.water.usgs.gov/twri9A7/.

National Oceanic and Atmospheric Administration, 2018a, State of the climate-National overview-Annual 2017: National Oceanic and Atmospheric Administration, National Centers for Environmental Information, accessed January 24, 2018, at https://www.ncdc.noaa.gov/sotc/ national/201513.

National Oceanic and Atmospheric Administration, 2018b, Climate at a glance-Missouri climate summary: National Oceanic and Atmospheric Administration, National Climatic Data Center database, accessed January 24, 2018, at https://www.ncdc.noaa.gov/cag/.
Otero-Benitez, W., and Davis, J.V., 2009a, Quality of surface water in Missouri, water year 2007: U.S. Geological Survey Open-File Report 2009-1096, 19 p., accessed October 17, 2017, at https://pubs.usgs.gov/of/2009/1096/.

Otero-Benitez, W., and Davis, J.V., 2009b, Quality of surface water in Missouri, water year 2008: U.S. Geological Survey Open-File Report 2009-1214, 18 p., accessed October 17, 2017, at https://pubs.usgs.gov/of/2009/1214/.

Patton, C.J., and Kryskalla, J.R., 2011, Colorimetric determination of nitrate plus nitrite in water by enzymatic reduction, automated discrete analyzer methods: U.S. Geological Survey Techniques and Methods, book 5, chap. B8, 48 p. [Also available at https://pubs.usgs.gov/tm/05b08/.]

Patton, C.J., and Truitt, E.P., 1992, Methods of analysis by the U.S. Geological Survey National Water Quality Laboratory-Determination of total phosphorus by a Kjeldahl digestion method and an automated colorimetric finish that includes dialysis: U.S. Geological Survey Open-File Report 92-146, 39 p. [Also available at https://doi.org/10.3133/ ofr92146.]

Sandstrom, M.W., Stroppel, M.E., Foreman, W.T., and Schroeder, M.P., 2001, Methods of analysis by the U.S. Geological Survey National Water Quality LaboratoryDetermination of moderate-use pesticides and selected degradates in water by $\mathrm{C}-18$ solid-phase extraction and gas chromatography/mass spectrometry: U.S. Geological Survey Water-Resources Investigations Report 01-4098, 70 p. [Also available at https://nwql.usgs.gov/pubs/WRIR/ WRIR-01-4098.pdf.]

Sandstrom, M.W., Kanagy, L.K., Anderson, C.A., and Kanagy, C.J., 2015, Determination of pesticides and pesticide degradates in filtered water by direct aqueousinjection liquid chromatography-tandem mass spectrometry: U.S. Geological Survey Techniques and Methods, book 5, chap. B11, 54 p., accessed March 19, 2018, at http://dx.doi.org/10.3133/tm5B11.

Sandstrom, M.W., and Wilde, F.D., 2014, Syringe-filter procedure for processing samples for analysis of organic compounds by DAI LC-MS/MS: U.S. Geological Survey Techniques of Water-Resources Investigations, book 9, chap A5 sec. 2.2.B, accessed February 20, 2018, at https://pubs.water.usgs.gov/twri9A5/.

Slater, L.J., and Villarini, G., 2017, Evaluating the drivers of seasonal streamflow in the U.S. Midwest: Water, v. 9 , no. 9 , p. 695 , accessed November 5, 2018, at https://doi.org/10.3390/w9090695.

U.S. Census Bureau, 2016, U.S. population estimates: U.S. Census Bureau, accessed October 17, 2017, at https://www.census.gov/. 
U.S. Environmental Protection Agency, 1997, Guidelines for preparation of the comprehensive State water quality assessments (305(b) reports) and electronic updates (1997): Washington, D.C., U.S. Environmental Protection Agency, Office of Water, EPA-841-B97-002A, [variously paged], accessed March 19, 2018, at https://www.epa.gov/tmdl.

U.S. Environmental Protection Agency, 2018, Impaired waters and TMDLs: U.S. Environmental Protection Agency, Impaired Waters and TMDL Program website, accessed March 19, 2018, at https://www.epa.gov/tmdl/ program-overview-impaired-waters-and-tmdls.

U.S. Geological Survey, 1964-2005, Water resources dataMissouri: U.S. Geological Survey, [variously paged].

U.S. Geological Survey, 2006a, Collection of water samples (ver. 2.0): U.S. Geological Survey Techniques of WaterResources Investigations, book 9, chap. A4, accessed February 9,2018 , at https://pubs.water.usgs.gov/twri9A4.

U.S. Geological Survey, 2006b-2010, Water resources data for the United States-Annual water-data report: U.S. Geological Survey, accessed February 9, 2018, at https://wdr.water.usgs.gov/.
U.S. Geological Survey, 2017, USGS water data for the Nation: U.S. Geological Survey National Water Information System database, accessed November 6, 2017, at https://doi.org/10.5066/F7P55KJN.

Wilde, F.D., ed., variously dated, Field measurements: U.S. Geological Survey Techniques of Water-Resources Investigations, book 9, chap. A6, accessed February 9, 2018, at https://pubs.water.usgs.gov/twri9A6/.

Wilde, F.D., Radtke, D.B., Gibs, J., and Iwatsubo, R.T., eds., 2004, with updates through 2009, Processing of water samples (ver. 2.2): U.S. Geological Survey Techniques of Water-Resources Investigations, book 9, chap. A5, accessed February 9, 2018, at https://pubs.water.usgs.gov/twri9A5/.

Zaugg, S.D., Sandstrom, M.W., Smith, S.G., and Fehlberg, K.M., 1995, Methods of analysis by the U.S. Geological Survey National Water Quality Laboratory-Determination of pesticides in water by $\mathrm{C}-18$ solid-phase extraction and capillary-column gas chromatography/mass spectrometry with selected-ion monitoring: U.S. Geological Survey Open-File Report 95-181, 49 p. [Also available at https://pubs.usgs.gov/of/1995/0181/report.pdf.]
For more information about this publication, contact:

Director, USGS Central Midwest Water Science Center

1400 Independence Road

Rolla, MO 65401

573-308-3667

For additional information, visit: https://www.usgs.gov/centers/cm-water
Publishing support provided by the

Rolla Publishing Service Center 


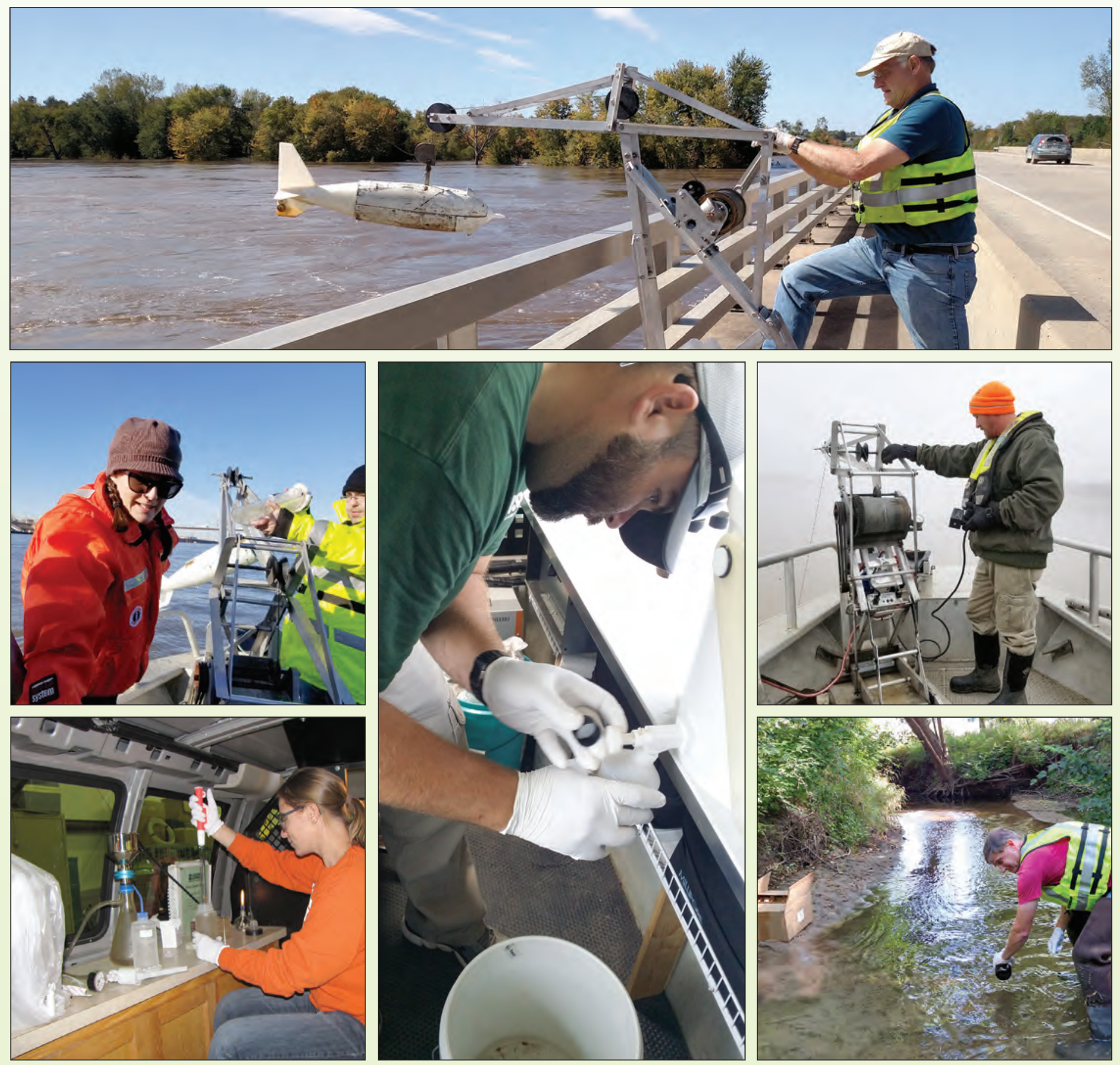

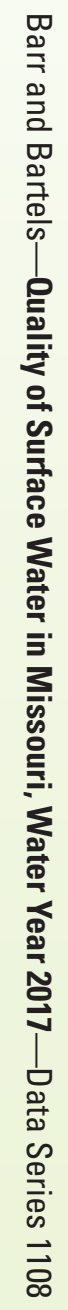

